Provided for non-commercial research and education use. Not for reproduction, distribution or commercial use.

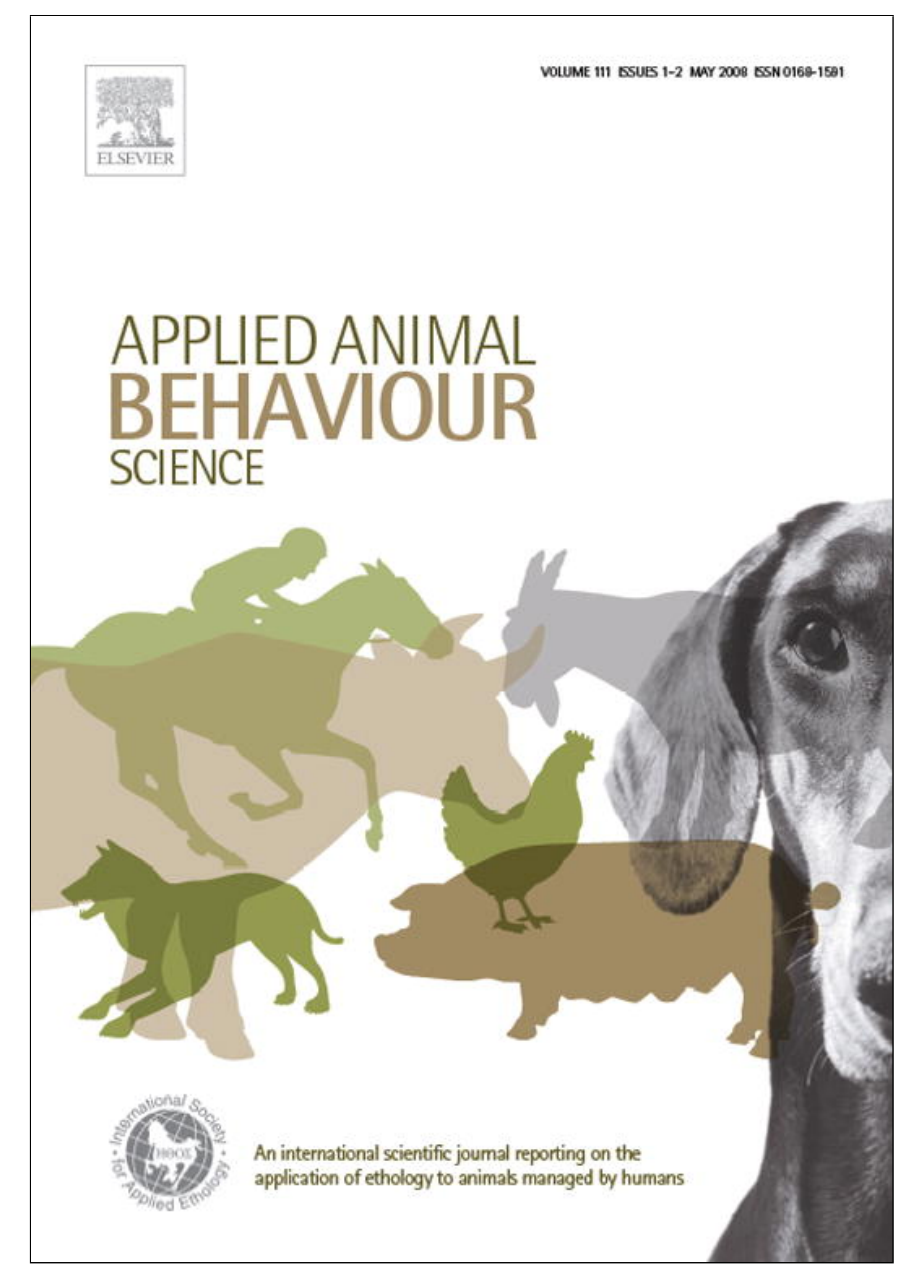

This article appeared in a journal published by Elsevier. The attached copy is furnished to the author for internal non-commercial research and education use, including for instruction at the authors institution and sharing with colleagues.

Other uses, including reproduction and distribution, or selling or licensing copies, or posting to personal, institutional or third party websites are prohibited.

In most cases authors are permitted to post their version of the article (e.g. in Word or Tex form) to their personal website or institutional repository. Authors requiring further information regarding Elsevier's archiving and manuscript policies are encouraged to visit:

http://www.elsevier.com/copyright 


\title{
Review
}

\section{To swim or not to swim: An interpretation of farmed mink's motivation for a water bath}

\author{
Claudia M. Vinke ${ }^{\mathrm{a}, *}$, Steffen W. Hansen ${ }^{\mathrm{b}}$, Jaakko Mononen ${ }^{\mathrm{c}}$, \\ Hannu Korhonen ${ }^{\mathrm{d}}$, Jonathan J. Cooper ${ }^{\mathrm{e}}$, Maarit Mohaibes ${ }^{\mathrm{c}}$, \\ Morten Bakken ${ }^{\mathrm{f}}$, Berry M. Spruijt ${ }^{\mathrm{a}}$ \\ ${ }^{a}$ Ethology \& Welfare Group, Department of Animals, Science \& Society, Faculty of Veterinary Medicine, \\ University of Utrecht, P.O. Box 80166, 3508 TD Utrecht, The Netherlands \\ ${ }^{\mathrm{b}}$ Faculty of Agricultural Sciences, Department of Animal Health, Welfare and Nutrition, \\ University of Aarhus, Blichers Allé 20, P.O. Box 50, 8830 Tjele, Denmark \\ ${ }^{\mathrm{c}}$ University of Kuopio, Department of Biosciences, P.O. Box 1627, FIN-70211 Kuopio, Finland \\ ${ }^{\mathrm{d}}$ Animal Production Research, MTT, Agrifood Research Finland, Fur Animal Section, \\ FIN-69100, Kannus, Finland \\ ${ }^{\mathrm{e}}$ Animal Behaviour Cognition and Welfare, Department of Biological Sciences, \\ University of Lincoln, Riseholme Park, Lincoln N2 2LG, United Kingdom \\ ${ }^{\mathrm{f}}$ Norwegian University of Life Sciences, Department of Animal and Aquacultural Sciences, \\ P.O. Box 5003, N-1432 Às, Norway
}

Accepted 21 February 2008

\begin{abstract}
How an animal's behavioural needs can be met is a pivotal issue in the assessment of welfare for captive animals. The value of swimming water for farmed mink is an example of how scientific and societal questions relating to animal welfare can be answered. A number of studies have addressed the issue of the indispensability of swimming water for mink; however, so far with inconclusive evidence. In this paper, the results of these studies and related literature are reviewed. First, the biological definition of need is discussed. Subsequently, we will review effects of the presence, absence and the removal of swimming water on behavioural and physiological correlates of well-being including stereotypic and anticipatory behaviour and urinary cortisol. Thereafter we will discuss individual differences in the use of swimming water, the price animals pay for access to a water bath, and the effect of access to swimming water on juvenile play. Our critical review of the available literature provides several conclusions: mink's water bath use appears primarily related to foraging behaviour; if mink have not had prior experience with swimming water the lack of this resource does not lead to consistent changes in stereotypic behaviour or anticipatory
\end{abstract}

\footnotetext{
* Corresponding author. Tel.: +31 30 2534373; fax: +31 302539227.

E-mail address: C.M.Vinke@uu.nl (C.M. Vinke).
} 
responses; when mink have had prior experience with swimming water, removal of this resource can induce short-term stress; most mink work hard for access to a swimming bath and running wheel in consumer demand studies; individual mink differ in how much they value a water bath: some mink never use a swimming bath; swimming water is likely not an "innate" need but rather an incentive that induces its own motivation.

(C) 2008 Elsevier B.V. All rights reserved.

Keywords: Farmed mink; Animal welfare; Biological need; Motivation; Swimming water; Animal housing

\section{Contents}

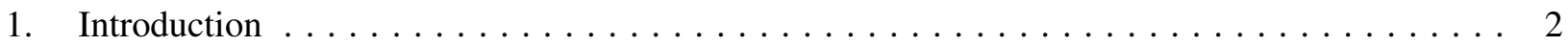

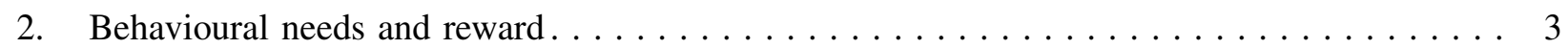

2.1. Behavioural needs: definitions, concepts and some characteristics $\ldots \ldots \ldots \ldots \ldots \ldots$

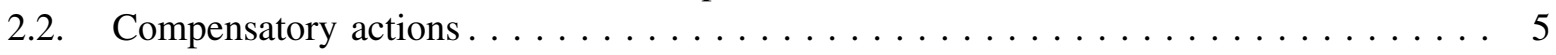

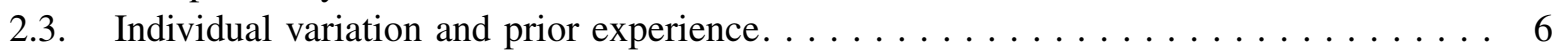

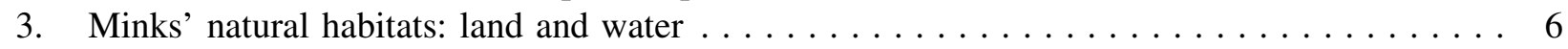

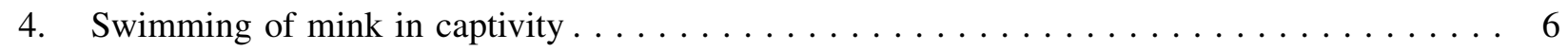

5. The presence or absence of swimming water and effects on stereotypical behaviour and

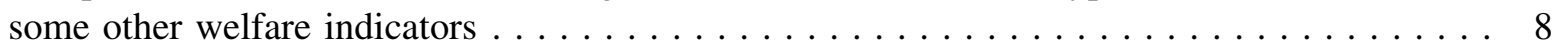

5.1. Stereotypies in the presence and absence of a water bath $\ldots \ldots \ldots \ldots \ldots \ldots \ldots$

5.2. The presence of swimming water may induce play behaviour $\ldots \ldots \ldots \ldots \ldots \ldots$

6. What is swimming water worth to mink and can it be substituted? . . . . . . . . 9

7. The effects of prior experience of a water bath and deprivation on some behavioural and

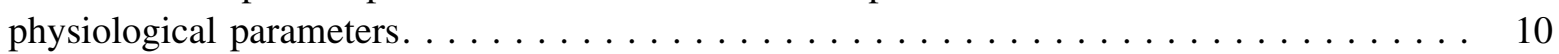

7.1. Blockage and removal of a swimming bath: deprivation dilemma? . . . . . . . 11

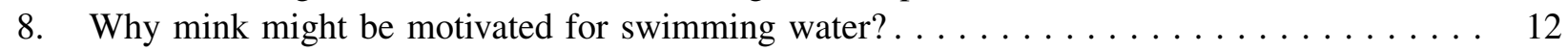

9. General comments on the available studies and data and evaluation of methods . . . . . 12

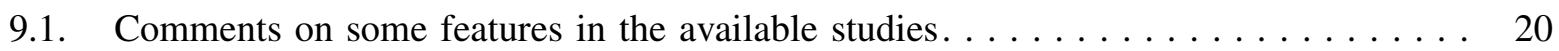

9.2. Some specific points of discussion on the results in the available studies . . . . . 20

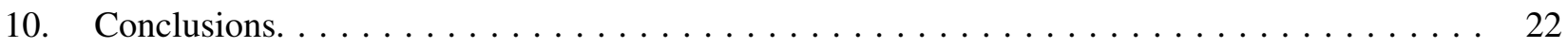

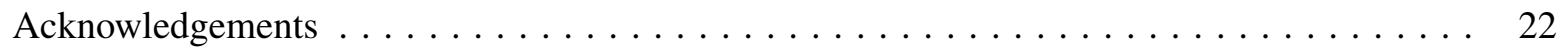

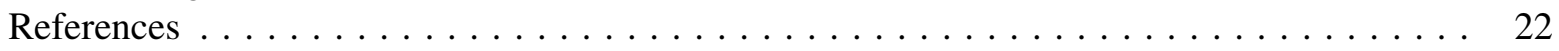

\section{Introduction}

The deprivation of behavioural or ethological needs is a key feature of poor welfare of animals kept in captivity (see Dawkins, 1988; Friend, 1989; Rushen et al., 1993). Animals have a certain degree of plasticity to adapt their behavioural repertoire to environmental demands; they can acquire new behaviours (learning), omit non-adaptive behaviours or adapt behavioural strategies to available resources. However, where behavioural plasticity is limited and the animal is equipped with specific behavioural strategies for the "standard" demands of the environment, the capacity to adapt is restricted (see for coping strategies: e.g. Fokkema et al., 1995; Koolhaas et al., 1999).

The role of swimming water for farmed mink has raised much debate on ethological needs with respect to scientific and societal concerns regarding animal welfare and related ethical 
issues. Whether access to swimming water represents a behavioural need for farmed mink, so far has not been resolved conclusively. Therefore, a concerted action of a combined set of studies was launched to attempt to resolve this issue: is swimming water an indispensable stimulus, a conditional need, or is swimming water not needed at all for farmed mink?

This paper aims to discuss the main results and conclusions of these studies (the separate full studies are published elsewhere) as well as other available literature on the meaning of swimming water for farmed mink. Attention is paid to the effects of the presence, the absence and the removal of swimming water (deprivation) on stereotypic behaviour, anticipatory activity, levels of urinary cortisol, individual differences in the use of water resources, preference and consumer demand studies, and the effect of swimming water on juvenile play as a potential positive indicator of animal well being. The present paper does not address animal management issues such as the economic consequences of the introduction of swimming water on farms, the potential legislation to cover swimming water delivery in different countries, nor the effect of swimming water on reproduction, pelt quality and health. Nor does this paper discuss the ethical aspects of the purpose for which mink is commercially bred.

The paper starts with a short summary on the concept of behavioural needs, followed by minks' natural habitats on land and water, and the use of swimming water by captive mink if water is freely available. Subsequently, we discuss: the development of stereotypies in farmed mink in the presence and absence of swimming water; consumer-demand tests and substitutability of alternative resources; the importance of prior experience with swimming water; anticipatory and juvenile play behaviour in the presence and absence of a water bath; and the effects of deprivation and challenges involved in the study of behavioural deprivation. Finally, we question why mink might be motivated to have swimming water, draw conclusions on the necessity of providing swimming water to farmed mink, and provide advice for future research and for farming practice.

\section{Behavioural needs and reward}

\subsection{Behavioural needs: definitions, concepts and some characteristics}

Behavioural needs or "what is indispensable to an animal", have been described in various ways. One approach is to reflect on the wild or natural environment and suggest all elements that are denied to animals in captivity can be described as either lacking or deprived (Thorpe, 1965; Martin, 1979). This approach has been largely rejected by animal welfare scientists, citing the organism's behavioural plasticity and the effects of domestication and humans' selective breeding programs (e.g. Dawkins, 1980, 1983; Poole, 1992; Veasey et al., 1996 Price, 1999) who concluded that it would be inappropriate to assume that captive animals would require the same elements in their environment as their wild counterparts.

A more classical definition of behavioural needs can be found in "Who needs behavioural needs?" by Jensen and Toates (1993). They defined a behavioural need as a specific behavioural pattern that should be performed, irrespective of the environment, even when the physiological needs related to this essential behaviour have been met. The biological relevance or adaptive value of performance of these types of behaviours may reside in long-term benefits for the individual or its offspring (e.g. behaviours concerning reproduction, foraging and grooming). It is often assumed that the motivation to perform these essential behavioural patterns is governed by an internal motivation (e.g. Friend, 1989) and that expression of the behaviour itself may have rewarding properties, as it is unlikely that the individual is capable of assessing long term efficacy 
or reproductive fitness. From a close point of view, the involvement of some reward can therefore underpin the regular performance of the display (see, e.g. Hernnstein, 1977; Spruijt et al., 1992, 2001). This concept of self-rewarding behaviours can be used to explain why certain behaviours such as exploration, foraging and grooming, still appear in the behavioural repertoires of captive animals, even when the functional benefits of their performance have been removed. More recently, Spruijt et al. (2001) investigated the neurobiological evidence for these rewards based on studies of addiction and affect (e.g. Berridge, 1996; Berridge and Robinson, 1998; Panksepp, 1998; Panksepp and Burgdorf, 2003) and by studying the link between neuronal structures and the (appetitive and consummatory) phases of behavioural patterns. Spruijt et al. (2001) described behavioural patterns in terms of appetitive and consummatory activities, where the appetitive components have been associated with mesolimbic dopamine (e.g. Schultz, 1998, 2000; Berridge, 1996; Panksepp, 1998). Panksepp (1998) had previously characterised the appetitive components as seeking behaviour; whereas Berridge (1996) characterised this motivational phase as wanting, whilst consummatory activities were more associated with liking.

Alternatively the term behavioural priority can be used instead of behavioural needs as introduced by Mason et al. (2001) and discussed by Cooper and Albertosa (2003). The term "behavioural priority" takes into account a hierarchy of requirements, in line with different motivations, whereby the need to satisfy these particular motivations depends on internal and external circumstances, as well as previous experiences and current circumstances and takes into account the motivational and emotional state of the particular individual (see Cooper and Albertosa, 2003). Hence, context is an important factor on describing behavioural needs and it may even critically address practical issues derived from precise definitions on behavioural needs (Jensen and Toates, 1993). For the purposes of this paper we shall use Jensen's and Toates' concept of behavioural needs as the conceptual framework to discuss the findings of empirical studies, as this has value to predicting the features we would expect of a behavioural need, and use the concept of behavioural priorities when assessing the relative importance of alternative resources as this has more practical value in farm welfare assessment than absolute definitions of needs.

Several characteristics of behavioural needs are mentioned in the literature. In short, some of the main characteristics of behavioural needs are: (1) Absence of stimuli that are indispensable for essential activities, or denying the actual performance of essential behavioural patterns, can induce a state of chronic stress, resulting into physiological and/or behavioural pathology (e.g. Hughes, 1980; Friend, 1989; van Liere and Wiepkema, 1992; Broom and Johnson, 1993; Jensen and Toates, 1993; Vestergaard et al., 1997); (2) The behaviour can be performed without the presence of eliciting cues (primarily internally motivated; e.g. Friend, 1989); (3) The behaviour is performed at a higher rate when the animal is first allowed to perform the behaviour after a period of deprivation ("damming-up": Friend, 1989 or rebound effects Vestergaard, 1982); (4) The presence of vacuum activities (Hughes and Duncan, 1988), i.e. animals deprived of an opportunity to perform an action might eventually show it even in the absence of the required stimuli: e.g. laying hens "dust bath" even when the dust bathing substrate is absent (see, e.g. Widowski and Duncan, 2000); (5) The display itself has rewarding properties, involving meso-limbic dopamine and opioids (see, e.g. Panksepp, 1998; Berridge, 1996; Spruijt et al., 2001). For a number of behaviours one could say that the display results in release of endorphins (opiate neuropeptide) which reinforce their occurrence: for example, social behaviour (van Ree et al., 1999), play (VanderSchuren et al., 1995a,b), and grooming (Spruijt et al., 1992) are facilitated by opioids and their occurance can decrease following treatment with an opiate antagonist. 
Two issues remain clear in the discussion of essential needs. Firstly, it is not possible to give precise standards on timing, duration and frequency that a particular 'indispensable' behavioural pattern should be performed by an individual member of the species, as this depends on the context (see Jensen and Toates, 1993; Cooper and Albertosa, 2003). As behavioural needs involve species specific patterns, the only sure statement to be made is that it seems evident that these particular patterns are performed by all individuals of that species, e.g. ingestion of nutrients, thus searching for food is essential to all animals (essential for survival: see Poole, 1992). It is to be expected, therefore, that these patterns can also be seen in captivity if the opportunity is there. Secondly, it is debatable how many of the aforementioned characteristics should be demonstrated before one should entitle a pattern as 'indispensable'. Alternatively, does the occurrence of just one of these characteristics indicate we should treat an activity as a behavioural need? Although an interesting topic for future scientific discussions, this paper does not aim to use this listing in this particular way. The list only involves some important issues that may be helpful to elucidate the discussion on minks' motivation for a swimming bath. These features can be found in many other discussions on behavioural needs and behavioural priorities in other species. Notable examples include the dust bathing behaviour of chickens (e.g. Vestergaard, 1980, 1982; Nicol and Guilford, 1991; Vestergaard et al., 1997, 1999; van Liere and Wiepkema, 1992; Petherick et al., 1995; Johnsen and Vestergaard, 1996; Lindberg and Nicol, 1997; Duncan et al., 1998; Widowski and Duncan, 2000; Nicol et al., 2001), nesting and pre-laying behaviour in the laying hen (e.g. Cooper and Appleby, 1995, 1996, 1997) and the rooting of pigs (e.g. Lawrence and Terlouw, 1993; Horrell et al., 2001; Studnitz and Jensen, 2002; Tuyttens, 2005).

\subsection{Compensatory actions}

Where the necessary eliciting stimuli for the display of an important behaviour are absent in the animals' environment, abnormal behaviours have been described (Fox, 1968). These include stereotypic behaviour, e.g. in the absence of rooting substrate for pigs (e.g. Lawrence and Terlouw, 1993) or hyperactivity and stereotypic behaviour in canids and polar bears when opportunities are absent to explore (e.g. Wechsler, 1991; Clubb and Mason, 2003). One hypothesis that links behavioural deprivation and stereotypic behaviours is the involvement of reward systems that may compensate for inability to interact with functional substrates or meet relevant behavioural endpoints (e.g. Cronin et al., 1985, 1986; Cabib, 1993; Cabib and PuglisiAllegra, 1996; Spruijt et al., 2001). The compensation hypothesis and its underlying mechanism are demonstrated on studies on play (e.g. VanderSchuren et al., 1995a,b, 1997): play deprived animals compensate by enhanced sucrose intake and increased bodyweight. Morphine counteracted this compensatory sucrose intake, perhaps because the absence of play-induced release of endorphins is compensated by morphine.

In this compensation hypothesis, the display of compensatory behaviours may be elicited if reward systems are sensitised by stress (see Piazza et al., 1990). Self rewarding behaviours, which still can be performed, are likely candidates to compensate for the "lack of reward" and may even be performed in a compulsive way. It is especially these kinds of behaviours (e.g. perseverance of intentional activities such as foraging patterns and self directed activities such as grooming), that appear to be prone to develop into stereotypic behaviours (e.g. Spruijt et al., 1992; Rushen et al., 1993; Spruijt et al., 2001), in case of frustration (e.g. Duncan and WoodGush, 1972; Mason, 1991), lack of stimulation (e.g. Mason, 1991; Broom and Johnson, 1993) and other chronic stressful conditions (e.g. Cronin and Wiepkema, 1984; Cronin et al., 1985; Mason, 1991; Broom and Johnson, 1993; Rushen et al., 1993). 


\subsection{Individual variation and prior experience}

The consequences of individual experience on the performance of particularly motivated behavioural patterns, and the longer-term need to perform these particular patterns are important areas of discussion. Behaviours that have to be performed even if the animal has never had experience of eliciting stimuli in the appropriate context (and have been described as motivated mainly by internal mechanisms patterns, Hughes, 1980; Hughes and Duncan, 1981), should appear different from an induced pattern of activity resulting from prior experience. The latter might be referred to as an "incentive induced need" or "incentive induced motivation" (as derived from drug addiction literature: e.g. van Ree et al., 1999). Compared to activities that are not incentive-induced, this leaves us the same theoretical question: how much can a particular individual subject suffer if denied from its "incentive induced need"? In practice, however, an incentive induced motivation may never have consequences for the animal if never provided. Thus, in view of animal welfare in practice the question still is: which behaviours form an indispensable part of the animal's repertoire and which are induced by prior experience and can be missed in captivity if the animal has no prior experience?

\section{Minks' natural habitats: land and water}

For the majority of the year, mink live solitarily in territories along waterways (Gerell, 1970; Birks, 1981; Dunstone, 1993) with more than one den site (Birks and Linn, 1982). Mink show great flexibility in prey species. Seasonal fluctuations in availability of prey, i.e. abundance and ease of capture, necessitate mink to have a flexible hunting strategy on land and in the water (Dunstone, 1993). Dunstone (1993, p. 63) mentioned two reasons why wild mink may choose to enter the water in search of prey: (1) either terrestrial prey becomes more difficult to capture than aquatic prey, or (2) there is an increase in the ease of exploitation of aquatic prey: e.g. lower ambient temperature decreases the escape reactivity of the poikilothermic fish prey (Gerell, 1967).

Mink's adaptations to under-water hunting are not as developed as the otter or more strictly aquatic animals (e.g. seals), but are appropriate and efficient: their fore- and hind feet are interdigitally webbed, they have a semi-water resistant pelt (mean pelt density from mid-back region: 780 hairs $/ \mathrm{cm}^{2}$, Dunstone, 1979), and they have some adaptation of the anatomy of the eyes to overcome the refractive problems involving underwater vision (Sinclair et al., 1974; Dunstone, 1993, p. 51). Results on respiratory adaptations to diving, like bradycardia, are not conclusive in the literature, but Dunstone (1993, p. 43) concluded that minks' dives, with a recorded maximum length up to $30 \mathrm{~s}$, are aerobic, i.e. carried out using the body's normal oxygen reserves. In addition to aquatic adaptations, mink can also run fast and see well on land, and so, appear to be well equipped to use both kinds of hunting habitats (see Dunstone, 1978).

\section{Swimming of mink in captivity}

In a semi-natural enclosure, juvenile mink were observed to start entering the water pool at the age of about seven weeks (Kuby, 1982). Poole and Dunstone (1976) mentioned that their experimental subjects, hand raised ranch-bred mink, had to be given experience of water at an early age or they never became proficient swimmers when adult. In their studies they trained each new batch of kits by encouraging them to swim. Interestingly, de Jonge and Leipoldt (1994) observed that the water bath was more attractive around feeding times. In general, they described 
mink's behaviour towards the water bath as "hesitating": the subjects stopped in front of the waterside and even sat along the water for long periods before entering the water; sometimes they accidentally fell into the water, but than the subjects always left the water quickly (cf de Jonge and Leipoldt, 1994, p. 142). In contrast, Kuby (1982, p. 56-57) described swimming as an "innate" pattern, and described the first swimming performance of one of his mink pups as looking "neither clumsy nor unsure".

The aquatic hunting of mink is thoroughly described by Poole and Dunstone (1976) based on series of laboratory observations and experiments. Most striking was their observation that fishes were generally detected by their mink subjects before they entered the water by the head dip, whereby a mink typically peers its head under water while having a continue grip on land with their hind feet; only when prey is localised they dive into the water (Dunstone, 1978; see Korhonen et al., 2003 for recent observations of head dipping on farms). In the water tank, mink demonstrated surface swimming as well as underwater swimming, whereas surface swimming was found to be the slowest mode of progression (38 cm/s, Dunstone, 1979). Mohaibes et al. $(2002,2003)$ studied the behaviour of farmed mink also in the winter period when the water in the water bath was partially or totally frozen: the partially frozen ice offered the subjects novel challenges and the mink started to creep into the cave-like holes in the ice, to dig the sludge and to manipulate parts of ice (Mohaibes et al., 2003).

Addressing the frequency of mink's use of water under farmed conditions, Skovgaard et al. (1997a,b), Hansen and Jeppesen (2001b), Mohaibes et al. (2001, 2002, 2003) showed clear individual differences in the use of the water bath. Some animals never entered the water: e.g. in the study of Skovgaard et al. (1997b) fourteen subjects of a total of forty animals provided with water never entered the bath; in the study of Hansen and Jeppesen (2001b) one of eleven subjects, recorded for $24 \mathrm{~h}$, did not swim.

Vinke et al. (2005) studied twenty-eight juvenile mink reared in the presence of a water bath and found that mink spent only $1.4 \%$ of observations in or around the water bath, with exploration of the bath and the head dip being the most frequently observed behaviours. This percentage was identical to the percentage for adult mink as observed by Skovgaard et al. (1997b)(1997b: 1.4\% of the total scans, in 40 subjects provided with a water bath). In a pilot study, de Jonge and Leipoldt (1994) observed seven adult females in cages with a water bath from 7 to $1 \mathrm{~h}$ before feeding time: they found that the females spent $0-11 \%$ of the time inside the water, and $2-27 \%$ around the water bath. Mink increased their time in and around the water bath before feeding time.

Mohaibes et al. (2003) observed forty-five female mink and found mean percentages of total observations of swimming of $0.35 \%( \pm 0.59$ S.D.; $N=14)$ in July and $0.60 \% \pm(0.57$ S.D.; $N=14$ ) in September-October. The percentage of observations in the swimming pool when the pools were partially frozen was 9.5\% ( \pm 5.0 S.D.; $N=14$ ). Hansen and Jeppesen (2001b) reported that the number of swims of eleven mink during $24 \mathrm{~h}$ ranged from 0 to 177; and that the durations of swimming bouts varied from 2 to $55 \mathrm{~s}$.

Hansen and Jeppesen (2000a,b) described an experimental design with three connected cages, having a water bath or an empty cage in the middle: the experimental subjects always had to pass the water bath or the empty cage to reach food or the nest box, or they could choose an alternative "dry-route" as created by a tunnel above the water bath. If the access to the opposite cages was only possible through the water bath, the animals appeared to be slower in reaching food and crossed less frequently between the food and the nest box, as compared to situations that they either could use the tunnel or had a dry middle cage. In addition, animals scratched more at the blocked tunnel access if the only available route was through the water, than when they could go 
through a dry middle cage. The latter may indicate that the mink preferred to use the alternative dry tunnel route to the food. The results suggest that under some circumstances or for some individuals, water can act as a barrier. Although these kinds of designs can yield further insight into the incentive value of water baths, the papers did not report the frequency of water- and tunnel passages in more detail and gave no insight whether the dry route might also be faster.

The frequencies of 'swimming' and 'around the water bath' may give some insight into the contribution of this particular pattern in farmed minks' time budget, nevertheless, they are not necessarily indicative of the value of swimming water for farmed mink: not all essential behavioural patterns should be expressed continuously in high frequencies to become classified as indispensable. This highly depends on other factors as well, e.g. sexes, age, observation season. On the other hand, the instance of the observed individual variation, with some individuals never entering the bath, is worth being addressed in the discussion.

\section{The presence or absence of swimming water and effects on stereotypical behaviour and some other welfare indicators}

\subsection{Stereotypies in the presence and absence of a water bath}

One of the best described behavioural pathologies in mink is the occurrence and development of stereotypies (see point [1] of the afore-mentioned characteristics of behavioural needs). In some studies the occurrence of stereotypies was observed both in the presence and absence of a water bath.

de Jonge and Leipoldt (1994) concluded that the availability of swimming water did not reduce stereotypical behaviours in adult mink ( $N=7$ females). Skovgaard et al. (1997a,b) studied adult mink in the absence and presence of swimming water. They concluded that free access to swimming water had no effects on reproduction (Skovgaard et al., 1997a; $N=64$; females and males) or on stereotypies (Skovgaard et al., 1997b; $N=64$; females and males). Hansen and Jeppesen (2001a) concluded that swimming water may not be classified as a behavioural need for mink, because the introduction of water was not followed by a reduction in stereotypical behaviour. Hansen (1998) reported an increased activity when the water was refreshed in the experimental water trays, "like that which is seen just before feeding time" (Hansen, 1990, 1998), but he found no effects on reproduction levels or immune responses. Some studies reported that mink subjects performed stereotypical patterns inside or in the presence of a water bath (Skovgaard et al., 1997a; Mohaibes et al., 2002, 2003; Vinke, 2004). Vinke et al. (2006) found no differences in anticipatory or in stereotypical behaviour in 4 months respectively 10 months old mink, in the presence and absence of swimming water ( $N=56$ females in total: 24 subjects with water and 24 without). Mohaibes et al. $(2002,2003)$ investigated the effects of a swimming bath on stereotypical behaviour: they found that mink with baths had less frequent stereotypic behaviour than mink without baths. This difference was statistically significant in Mohaibes et al. (2002), although only a tendency was found in Mohaibes et al. (2003).

In conclusion, it appears that in most studies the presence of swimming water does not significantly influence the levels of stereotypies or other parameters (e.g. reproduction, immune response, anticipatory behaviour). However, stereotypical behaviours can require some time to develop (e.g. Mason, 1991; Mason, 1993a,b): most of the studies cited above used adult mink. Future research should follow the development of stereotypies and other behaviours in mink with and without access to a water bath. 


\subsection{The presence of swimming water may induce play behaviour}

Vinke et al. (2005) demonstrated increased play in juvenile mink with access to swimming water. No significant relation could be found between juvenile play and stereotypical behaviour in adulthood. Nevertheless, the observation of play can be of interest for welfare assessment, as play is not performed under stressful conditions (Lawrence, 1987; Broom and Johnson, 1993). In rats, it has been shown that juvenile play is necessary for coping with social stress in adulthood (van den Berg, 1999; van den Berg et al., 1999a,b; von Frijtag, 2001; von Frijtag et al., 2002). Play is a typical example of a behavioural pattern with long-term adaptive value, but without high priority in a short term. Additionally, play involves opioids (VanderSchuren et al., 1995a,b). Play, therefore, has been proposed as a positive indicator of animal welfare.

\section{What is swimming water worth to mink and can it be substituted?}

As discussed above, a water bath may mean either a reward or a barrier for some mink. The question still remains: is swimming water merely enriching, or is its presence indispensable for farmed mink? Methods to assess the animal's appraisal of its situation are: (i) assessing the price the animal is willing to pay for access as addressed by consumer-demand studies (e.g. Dawkins, 1983, 1990; Mason et al., 1997, 1999; Cooper and Mason, 1997, 2000) and (ii) assessing the sensitivity of the reward systems as addressed by studies measuring the intensity of anticipatory behaviour (e.g. von Frijtag et al., 2000, 2001; Spruijt et al., 2001; van der Harst, 2003; van der Harst et al., 2003, Vinke et al., 2004b, 2006; Dudink et al., 2006). Theoretically, anticipatory behaviour preceding an incentive can be induced without previous experience of swimming water. Thus, this method can be applied to assess and compare the sensitivity of the reward system of mink in the presence, absence and after deprivation of a swimming bath, and so, may give some insight into the effects of experience on swimming motivation ("can you miss what you do not know?"). Consumer demand tests are used to assess how the animal values different resources and are especially based on two techniques borrowed from human economics: (1) the measurement of elasticity of demand and (2) the measurement of income elasticity (Mason et al., 1997). It is assumed that the resources that are valued highly by the animal are inelastic: the animal will invest much energy, e.g. press more weight, to get access to this resource. In human society, the market of bread or rice as basic foods, are called inelastic as people will remain to buying it, whatever the price. On the contrary, all kinds of luxury products like cars can be seen as elastic.

In a consumer-demand set-up of Mason et al. (2001), eight male and eight female mink could choose to "pay" (i.e. push doors with variable weights: $0,0.25,0.5,0.75 .1$ or $1.12 \mathrm{~kg}$ for seven successive days) for access to either a water bath, an alternative nest site, novel objects, a raised platform, toys, a tunnel or an empty cage. They found that farmed mink, with the exception to food, rated the water bath as the most valuable resource, as it attracted the greatest total expenditure and the highest reservation price, greatest consumer surplus measures of utility, and the most inelastic demand (Mason et al., 2001, p. 35).

In a subsequent study, the direct influence of stimuli eliciting the motivation to swim was excluded ("Is out of sight out of mind?"): Warburton and Mason (2003) studied the hierarchy of four test resources (i.e. food, water bath, social contact and toy), in two ways: (1) "cues treatment": resource cues were present when preference was expressed and (2) "no cues treatment": resource cues were distant and (visually) screened at the choice point $(N=6$ in both treatments). They reported that food was preferred in both treatments, but motivation for toys and 
possibly also unpredictable social contact declined in the "no cue treatment". They tentatively suggested that the visibility of water might have little effect on the motivation for the water bath. Thus, water cues do not elicit the need for it, although this does not address the issue of experience. Previous findings on the preference on resources of farmed mink in the study of Mason et al. (2001) were most closely replicated by the findings from the "No Cues treatment" in the study of Warburton and Mason (2003), which might appear paradoxical in the sense that in the first study the cues were available at the point of preference measurement. Differences between the two separate studies might be explained by the small sample size, differences between mink and breeding lines, the water bath designs used and effects of habituation.

Hansen and Jensen (2006a,b) also used a consumer-demand design to assess the rewarding properties of a water bath and a running wheel either separately, in a situation whereby both resources were present at the same time, and in a situation whereby one of the experimental resources was "free" (no pay) and the alternative was not. The subjects in this design could pay costs by pressing a lever on fixed ratio schedules varying from 5 to 60 times. There were no differences between the elasticity of the demand for swimming water and a running wheel, indicating that mink valued these two types of cage enrichment similarly. However, mink needed more rewards to lower the motivation for locomotive activity in the running wheel (higher intensity of the curve) than to lower the motivation for exploration in the water. Each supposed occupational enrichment has to be evaluated in relation to the motivation behind the use of the actual resource, but in the present experiment the running wheel had a higher occupational value for the mink than the water bath.

The simultaneous presence of both resources did not affect the demand for either running wheel nor swimming water in the study of Hansen and Jensen (2006a,b). Furthermore, with free access to either mink did not increase their use of the running wheel as the price of swimming water increased, nor their use of swimming water as the price of running wheel increased. Therefore, the two resources did not appear to be a substitute for each other. Both a running wheel and swimming water were valued higher than access to an empty water box. Mink mainly used the running wheel during their normal activity periods, whereas, the swimming water was primarily used in the morning when the water box was refilled and the mink were fed. Based on the lack of substitutability between the two resources and the different diurnal patterns, it was suggested that different motivations underlie the two test resources.

\section{The effects of prior experience of a water bath and deprivation on some behavioural and physiological parameters}

Prior experience of a water bath might influence an animal's motivation to use a bath. In the literature, we found some studies addressing the effects of deprivation of a previously experienced water bath and subsequent deprivation.

In the studies of Mohaibes et al. $(2002,2003)$ mink with swimming bath experience for several weeks were deprived of their baths for 2 weeks by blocking the access to the bath. In both studies the average values for the amount of stereotypies were higher during than before or after the deprivation, but it was not reported whether these differences were statistically significant. Furthermore, addressing the amount of stereotypies during deprivation in the bath group, the subjects did not differ significantly from two control groups deprived of access to an extra cage (of the size of the bath) or deprived of nothing (Mohaibes et al., 2003). During the deprivation period all three groups had available standard mink cages with standard nest boxes. 
In another study, conditions with a water bath and without a water bath (standard housing) did not change the level mink's anticipatory behaviour preceding a food reward. Neither was the level of anticipatory behaviour significantly affected after a 2-week deprivation of swimming water whereby the water was removed from the bath (Vinke, 2004; Vinke et al., 2006: watergroup and control-group: $2 \times 14$ subjects, each split into: Cue-US treatment $N=7$ vs. Cue-no CS treatment, $N=7$ as a control for anticipation). In rats, it has been shown that enrichment reduces anticipatory behaviour preceding a food reward and that isolation stress increased this behaviour (van der Harst, 2003). Therefore, the result obtained in mink might suggest that mink valued swimming water and the empty bath in a similar way, though larger samples would be needed in the study of Vinke et al. (2006) to rule out type II errors.

Addressing physiological parameters, Mason et al. (2001) found higher increased levels of the stress hormone cortisol in urine samples, $24 \mathrm{~h}$ after blocking the access to a swimming bath. Compared to baseline values and to other situations with blocked incentives, the increased cortisol levels indicate that the value of swimming water might be higher than the value of other enriching objects in the test with the exception of food, which likewise increased the level of urinary cortisol. In a more recent study, Warburton and Mason (2006, p. 77) found that preventing bath-access significantly induced access attempts ("scrabbling"), although they found no significant corticosteroid response. In addition, Korhonen et al. (2003) found increased levels of urinary cortisol-creatinine and corticosterone-creatinine ratios after blocking access to swimming water: the adrenocortical response was highest during the second week of deprivation and decreased thereafter. These results indicate a short-term stress ( $24 \mathrm{~h}-2$ weeks) after a period of deprivation by blocking.

An alternative explanation of increased levels of cortisol might be found in the fact that mink prefer to drink from the water bath (Hansen and Jeppesen, 2003) instead of their water bottle or drink nipple. Consequently, mink that are denied access to the water bath may drink less for a period which may also enhance the cortisol levels (Tauson, 1999). A recent study of Warburton and Mason (2006, p. 77) found that the cortisol levels were not changed significantly when preventing the access to the bath. No information was available on the level of water consumption.

Korhonen et al. (2003) reported that the deprivation of swimming water did not alter the occurrence of stereotypical behaviour and that no vacuum activities (point 5 in the characteristics of behavioural needs) have been reported in mink in relation to swimming water. The expression of vacuum activities in relation to swimming water remains unclear in the literature. The same can be concluded for rebound effects: rebound effects (point 4) after a period of deprivation are rarely described. Korhonen et al. (2003) reported no rebound response in behaviours such as swimming, head dipping or staying on the jetty after the deprivation of swimming water was discontinued. A study of Cooper and Mason (2000, p. 147) reported a drop in the number of compartment visits combined with more intensive interactions with the swimming pool, i.e. more bouts of swimming were performed per visit, when entry prices increased. More intense interactions with the resource once the cost has been overcome might point to a kind of rebound effect, but this case is difficult to interpret.

\subsection{Blockage and removal of a swimming bath: deprivation dilemma?}

Korhonen et al. (2003) reported a tendency to increase the amount of biting/scratching the cage as a result of deprivation (i.e. blocking the entry), which suggests a general increase of restlessness. Furthermore, removing the water bath out of sight or removing the water and leaving an empty bath, resulted in increased levels of stereotypical behaviour, tail biting and cortisol 
levels in the blocking-treated subjects (Mason et al., 2001; Korhonen et al., 2003; Vinke, 2004). It should be considered that the blockage of an entry door to which an animal had prior access to, might be stressful regardless of what is behind that door, e.g. swimming water, nest boxes, space (Hansen and Jeppesen, 2000a,b; see for a discussion Vinke, 2004). The removal of the whole bath from the cage preferably out of sight of the animal, therefore, might be a better experimental design for deprivation studies. Finally, it should be noted that deprivation studies always imply that animals have been in contact with swimming water, and thus, that the results might indicate on pure incentive-induced motivations.

In conclusion, deprivation of swimming water by blocking influences some physiological parameters on adrenocortical responses, indicating a higher level of stress at least on the short term. The way animals are deprived of a test incentive, blocking vs. removal, is a point of discussion and should be elucidated in future studies. So far, prior experience of swimming water seems to have little effect on stereotypical behaviour and anticipatory behaviour.

\section{Why mink might be motivated for swimming water?}

As the meaning of swimming water for farmed mink can be variable, different underlying motivations for the use of a water bath should be taken into account: do mink use a water bath for thermoregulation, as an easy drinking site, additional space (in most studies represented by empty baths), or as an exploration and foraging opportunity? Hansen and Jeppesen (2003) concluded that swimming water is not used as a thermoregulatory mechanism by mink, as their experimental subjects did not show increased levels of swimming at high temperatures. Based on the level of the water emerged from the basin, Vinke et al. (2004a) found that the mink used the water bath considerably less during high ambient temperatures which was the consequence of a general decrease in all activities. This is in line with the prior study of Hansen and Jeppesen (2003). The topic of easy drinking was studied by Mason et al. (1999): in a consumer-demand experiment, mink chose for a water bath in order to drink and swim. To exclude the swimming and drinking motivation, a water bowl was provided for free for "easy drinkable water": the subjects still worked for swimming. These findings were affirmed by a more recent study of Warburton and Mason (2006, p. 77). Mason et al. (2001) also controlled for the value of additional space and exploration objects but found lower preferences for these choices than for the access to a water bath.

Although not totally elucidated, the meaning of a water bath for mink seems most likely related to foraging behaviour: on land (running, exploring sides) or in the water (exploring, head dipping, swimming) (Hansen and Jensen, 2006a,b). The observation that the swimming bath seemed especially attractive around feeding times (e.g. de Jonge and Leipoldt, 1994) suggests that a water site may stimulate exploration to or into the water as a part of appetitive feeding behaviour. The inability to display adequate foraging behaviour is mentioned as a main cause of the development of stereotypical behaviour in captive animals (e.g. pigs: Terlouw et al., 1991; Mason and Mendl, 1997), but this seems not unequivocally the case in mink. Hypothetically, as mink appear opportunists and are able to adapt to different environments, farmed mink as well might be able to cope with different situations (with and without water) if the housing system provides enough alternative and adequate stimuli.

\section{General comments on the available studies and data and evaluation of methods}

Before making our final conclusions, we provide some general comments on the studies we have reviewed. Table 1 summarizes some of the features described in these papers (e.g. the water 
Table 1

Overview of some quality parameters in different studies addressing minks' appraisal for water baths

\begin{tabular}{|c|c|c|c|c|c|c|c|c|c|c|c|c|}
\hline $\begin{array}{l}\text { Authors of } \\
\text { the paper }\end{array}$ & $\begin{array}{l}\text { Measures of } \\
\text { the water } \\
\text { bath }\end{array}$ & $\begin{array}{l}\text { Water } \\
\text { hygiene }\end{array}$ & $\begin{array}{l}\text { Sample } \\
\text { size } \\
(N)\end{array}$ & $\begin{array}{l}\text { \# Subject } \\
\text { using } \\
\text { bath }\end{array}$ & $\begin{array}{l}\text { Used } \\
\text { method(s) }\end{array}$ & $\begin{array}{l}\text { Used } \\
\text { measures }\end{array}$ & $\begin{array}{l}\text { Colour } \\
\text { type }\end{array}$ & $\begin{array}{l}\text { Age of } \\
\text { subjects }\end{array}$ & 우 & $\begin{array}{l}\text { Time of } \\
\text { observation }\end{array}$ & $\begin{array}{l}\text { Season of } \\
\text { observations }\end{array}$ & $\begin{array}{l}\text { Inside/ } \\
\text { outside }\end{array}$ \\
\hline $\begin{array}{l}\text { Cooper and } \\
\text { Mason } \\
(2000)\end{array}$ & $\begin{array}{l}\text { A bathtub; } \\
\text { water depth: } \\
15 \mathrm{~cm}\end{array}$ & $\begin{array}{l}\text { Cleaned } \\
\text { every } 2 \\
\text { weeks or } \\
\text { when } \\
\text { soiled }\end{array}$ & $\begin{array}{l}N=6 \\
(3 \AA ; 3 \text { 우) }\end{array}$ & $6 / 6$ & $\begin{array}{l}\text {-Consumer- } \\
\text { demand (door } \\
\text { weights:0, } \\
250,500, \\
750,1000 \mathrm{~g}) \\
\text {-Behavioural } \\
\text { observation }\end{array}$ & $\begin{array}{l}\text {-Door weights__ } \\
\text { \# visit per } \\
\text { compartment, } \\
\text { visit duration, } \\
\text { bout length, } \\
\text { latency to interact } \\
\text {-e.g. locomotion, } \\
\text { rest swim, } \\
\text { groom, eat, } \\
\text { drink }\end{array}$ & wild & $6 \mathrm{~m}$ & o & $\begin{array}{l}8: 00- \\
\text { 16:00 } 5 \\
\text { test days; } \\
8 \mathrm{~h} / \text { day } \\
\text { video } \\
\text { recording } \\
\text { of each } \\
\text { mink }\end{array}$ & Autumn & In \\
\hline \multirow[t]{2}{*}{$\begin{array}{c}\text { Hansen and } \\
\text { Jeppesen } \\
\text { (2000a) }\end{array}$} & $\begin{array}{l}\text {-Large unit } \\
\text { (in fox cage): } \\
\text { L.120 cm } \times \\
\text { W. } 65 \mathrm{~cm} \text {; water } \\
\text { depth: } 15 \mathrm{~cm} \\
\text {-Small unit } \\
\text { (in standard } \\
\text { mink cage): } \\
\text { L. } 90 \mathrm{~cm} \times \\
\text { W. } 30 \mathrm{~cm} \text {; water } \\
\text { depth: } 15 \mathrm{~cm}\end{array}$ & $\begin{array}{l}\text { Cleaned } \\
\text { and refilled } \\
\text { weekly }\end{array}$ & $\begin{array}{l}\text { Large unit: } \\
20 \text { with } \\
\text { water }\end{array}$ & - & $\begin{array}{l}\text {-Behavioural } \\
\text { observation: } \\
\text { scan sampling } \\
\text { with } 10 \mathrm{~min} \\
\text { interval; } 9 \\
\text { days; } 10 \text { scans/ } \\
\text { subject/day }\end{array}$ & $\begin{array}{l}\text { Freq. of } \\
\text { stereotypies, } \\
\text { scratching } \\
\text { the barrier; } \\
\text { inactivity }\end{array}$ & - & $1-2$ years & $\hat{o}$ & $\begin{array}{l}\text { Half of } \\
\text { the group } \\
\text { morning, } \\
\text { other half } \\
\text { afternoon }\end{array}$ & $\begin{array}{l}\text { Summer } \\
1997\end{array}$ & Out \\
\hline & & & $\begin{array}{l}\text { Small unit: } \\
19 \text { with } \\
\text { water } \\
\text { Total } \\
\text { water: } 39\end{array}$ & & & & & & & & & \\
\hline $\begin{array}{l}\text { Hansen and } \\
\text { Jeppesen } \\
\text { (2000b) }\end{array}$ & $\begin{array}{l}\text { L. } 90 \mathrm{~cm} \times \\
\text { W. } 30 \mathrm{~cm} \text {; } \\
\text { water depth: } \\
15 \mathrm{~cm}\end{array}$ & $\begin{array}{l}\text { Cleaned } \\
\text { and } \\
\text { refilled } \\
\text { weekly }\end{array}$ & $\begin{array}{l}N=38++ \\
8 \hat{0}\end{array}$ & - & $\begin{array}{l}\text {-Behavioural } \\
\text { observation: } \\
\text { focal animal } \\
\text { sampl. } 2 \mathrm{~h} 8 \\
\text { subject/day, } \\
\text { of a total } \\
\text { of } 20 \text { days }\end{array}$ & $\begin{array}{l}\text {-Freq., } \\
\text { duration, } \\
\text { latency: } \\
\text { stereotypies, } \\
\text { scratching } \\
\text { the barrier; } \\
\text { inactivity. }\end{array}$ & - & $\begin{array}{l}2 \text { years } \\
\text { (except } \\
\text { for } 4 \text { 우) }\end{array}$ & 우 & $\begin{array}{l}9: 00- \\
14: 00 \mathrm{~h}\end{array}$ & $\begin{array}{l}1 \text { July-23 } \\
\text { July } 1997\end{array}$ & Out \\
\hline
\end{tabular}


Table 1 (Continued)

\begin{tabular}{|c|c|c|c|c|c|c|c|c|c|c|c|c|}
\hline $\begin{array}{l}\text { Authors of } \\
\text { the paper }\end{array}$ & $\begin{array}{l}\text { Measures of } \\
\text { the water } \\
\text { bath }\end{array}$ & $\begin{array}{l}\text { Water } \\
\text { hygiene }\end{array}$ & $\begin{array}{l}\text { Sample } \\
\text { size } \\
(N)\end{array}$ & $\begin{array}{l}\text { \# Subject } \\
\text { using } \\
\text { bath }\end{array}$ & $\begin{array}{l}\text { Used } \\
\text { method(s) }\end{array}$ & $\begin{array}{l}\text { Used } \\
\text { measures }\end{array}$ & $\begin{array}{l}\text { Colour } \\
\text { type }\end{array}$ & $\begin{array}{l}\text { Age of } \\
\text { subjects }\end{array}$ & q & $\begin{array}{l}\text { Time of } \\
\text { observation }\end{array}$ & $\begin{array}{l}\text { Season of } \\
\text { observations }\end{array}$ & $\begin{array}{l}\text { Inside/ } \\
\text { outside }\end{array}$ \\
\hline & & & & & $\begin{array}{l}\text {-Included } \\
\text { water } \\
\text { deprivation }\end{array}$ & & & & o & $\begin{array}{l}\text { Morning } \\
\text { and noon } \\
\text { observations } \\
\text { on reversal } \\
\text { scheme }\end{array}$ & & \\
\hline \multirow[t]{2}{*}{$\begin{array}{l}\text { Hansen and } \\
\text { Jeppesen } \\
\text { (2001a) }\end{array}$} & $\begin{array}{l}\text { See Hansen } \\
\text { and Jeppesen } \\
\text { (2000a) }\end{array}$ & $\begin{array}{l}\text { Cleaned } \\
\text { and refilled } \\
\text { weekly }\end{array}$ & $\begin{array}{l}\text { See Hansen } \\
\text { and Jeppesen } \\
\text { (2000a) }\end{array}$ & - & $\begin{array}{l}\text {-Behavioural } \\
\text { observation: } \\
\text { scan sample; } \\
141 \text { observations } \\
\text { /subject }\end{array}$ & $\begin{array}{l}\text {-Position } \\
\text { Stereotypies }\end{array}$ & - & Adult & 우 & $\begin{array}{l}\text { "Morning } \\
\text { hours" }\end{array}$ & $\begin{array}{l}\text { First } 2 \\
\text { weeks of } \\
\text { Aug } 1998\end{array}$ & Out \\
\hline & & & & & & & & & $\hat{o}$ & $\begin{array}{l}\text { After that } \\
\text { scans every } \\
10 \text { min. } \\
\text { interval }\end{array}$ & & \\
\hline \multirow[t]{2}{*}{$\begin{array}{l}\text { Hansen and } \\
\text { Jeppesen } \\
\text { (2001b) }\end{array}$} & $\begin{array}{l}\text { See Hansen } \\
\text { and Jeppesen } \\
\text { (2000a) }\end{array}$ & $\begin{array}{l}\text { Cleaned and } \\
\text { refilled } \\
\text { weekly }\end{array}$ & $\begin{array}{l}N=329+ \\
8 \hat{0} \rightarrow 11 \\
\text { subjects with } \\
\text { water video } \\
\text { recorded } \\
(6 \text { "heavy } \\
\text { users"; small } \\
\text { unit }=5, \\
\text { large unit =6) }\end{array}$ & $10 / 11$ & $\begin{array}{l}\text {-Behavioural } \\
\text { observation: } \\
\text { focal animal } \\
\text { sample }\end{array}$ & $\begin{array}{l}\text {-Frequency } \\
\text { and duration } \\
\text { of swimming } \\
\text { bouts }\end{array}$ & - & Adult & 우 & $\begin{array}{l}1 \times 24 \mathrm{~h} \\
\text { video } \\
\text { recording. }\end{array}$ & Aug 1998 & Out \\
\hline & & & & $(90 \%)$ & & $\begin{array}{l}\text {-Water loss } \\
\text { basin (each } \\
\text { week) + } \\
\text { ambient temp. }\end{array}$ & & & o & & $\begin{array}{l}\text { From autumn } \\
\text { 1994-Aug } 1998\end{array}$ & \\
\hline $\begin{array}{l}\text { Hansen and } \\
\text { Jeppesen } \\
\text { (2003) }\end{array}$ & $\begin{array}{l}\text { L. } 42 \mathrm{~cm} \times \\
\text { W. } 26 \mathrm{~cm} \text {; } \\
\text { water depth: } \\
12 \mathrm{~cm}\end{array}$ & $\begin{array}{l}\text { Refilled } \\
\text { each day }\end{array}$ & $\begin{array}{l}N=12(3 \\
\text { groups } \\
\text { of } 4 \text { mink) }\end{array}$ & $\begin{array}{l}10 / 12 \\
(83 \%)\end{array}$ & $\begin{array}{l}\text {-Behavioural } \\
\text { observation: } \\
\text { scan sample } \\
\text { + one zero } \\
\text { sample }\end{array}$ & $\begin{array}{l}\text {-Stereotypies; } \\
\text { activity }\end{array}$ & - & $1-4$ years & 우 & $\begin{array}{l}\text { Day 3; } 23 \mathrm{~h} \\
\text { video } \\
\text { recording }\end{array}$ & $\begin{array}{l}\text { Group I: } 6 \\
\text { Sept } 1999-17 \\
\text { Oct } 1999\end{array}$ & In \\
\hline
\end{tabular}


NB. Temp.

Sequences

were used

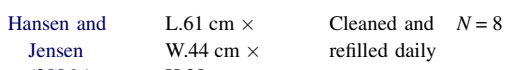

(2006a)

H. $28 \mathrm{~cm}$

Consumer-

demand

$\begin{array}{cll}\text { Hansen and } & \text { L. } 61 \mathrm{~cm} \times & \begin{array}{l}\text { Cleaned and } \\ \text { refilled daily }\end{array}\end{array}$

H. $28 \mathrm{~cm}$.

-Position

FR schedule ever pressing

$(1,5,10$,

$20,40)$

(2)

total running

$24 \mathrm{~h}$, total

swimming $24 \mathrm{~h}$

Consumer-

-Elasticity

of demand

Scan 1 years

brown

FR schedule

lever pressing

$(1,5,10$,

-Consumer

surplus

-Intensity

-Area

-\# rewards/day

e.g. bout lengths,

total running

$24 \mathrm{~h}$, total

swimming $24 \mathrm{~h}$

$6 / 7$
$(86 \%)$

-Behavioural

observation:

Freq. e.g.

stereotypies,

swimming,

$\begin{array}{ll}100 \text { sessions } & \text { sitting next } \\ \text { to the bath }\end{array}$

$\begin{array}{ll}100 \text { sessions } & \text { sitting next } \\ \text { to the bath }\end{array}$
Day 4: $24 \mathrm{~h}$ Group II:

video 18 Oct

1999-30

Nov 1999

2000

Automa-

$24 \mathrm{~h}$

registration
Wild Adult

ㅇ $8: 00-14: 00$

28 March-

$15 \mathrm{Apr}$.
Out 
Table 1 (Continued)

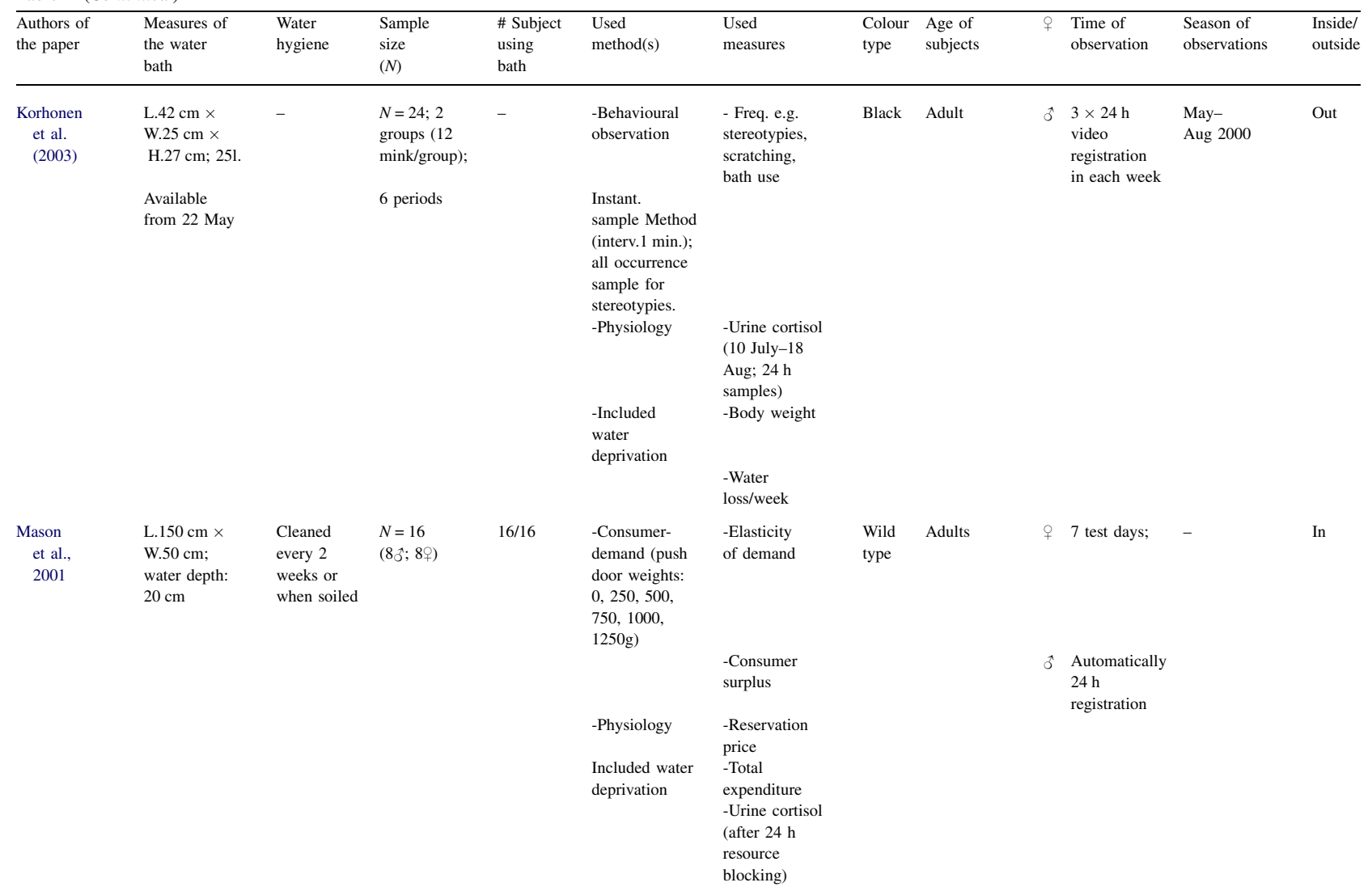




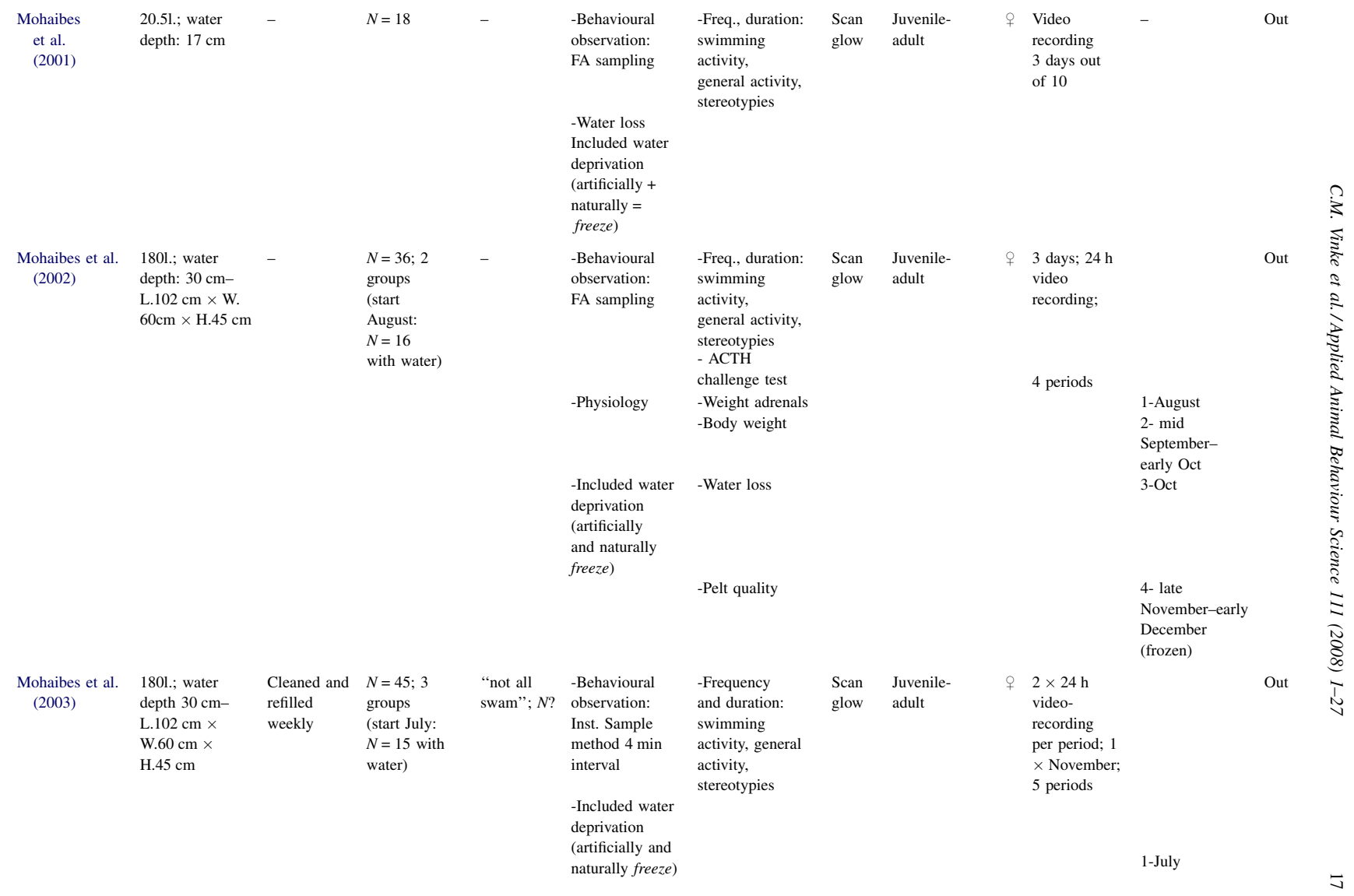




\begin{tabular}{|c|c|c|c|c|c|c|c|c|c|c|c|c|}
\hline $\begin{array}{l}\text { Authors of } \\
\text { the paper }\end{array}$ & $\begin{array}{l}\text { Measures of } \\
\text { the water } \\
\text { bath }\end{array}$ & $\begin{array}{l}\text { Water } \\
\text { hygiene }\end{array}$ & $\begin{array}{l}\text { Sample } \\
\text { size } \\
(N)\end{array}$ & $\begin{array}{l}\text { \# Subject } \\
\text { using } \\
\text { bath }\end{array}$ & $\begin{array}{l}\text { Used } \\
\text { method(s) }\end{array}$ & $\begin{array}{l}\text { Used } \\
\text { measures }\end{array}$ & $\begin{array}{l}\text { Colour } \\
\text { type }\end{array}$ & $\begin{array}{l}\text { Age of } \\
\text { subjects }\end{array}$ & 우 & $\begin{array}{l}\text { Time of } \\
\text { observation }\end{array}$ & $\begin{array}{l}\text { Season of } \\
\text { observations } \\
\text { 2-Sept }\end{array}$ & $\begin{array}{l}\text { Inside/ } \\
\text { outside }\end{array}$ \\
\hline & & & & & & & & & & & $\begin{array}{l}\text { 3-Sept-Oct } \\
\text { 4-Oct } \\
\text { 5-Nov-dec }\end{array}$ & \\
\hline \multirow[t]{2}{*}{$\begin{array}{l}\text { Skovgaard } \\
\text { et al. } \\
\text { (1997a) }\end{array}$} & $\begin{array}{l}\text { See Hansen } \\
\text { and Jeppesen } \\
\text { (2000a) }\end{array}$ & $\begin{array}{l}\text { Cleaned } \\
\text { and refilled } \\
\text { weekly }\end{array}$ & $N=64$ & - & $\begin{array}{l}\text { Reproduction } \\
\text { assessment }\end{array}$ & -Litter size & - & $\begin{array}{l}\text { From juvenile- } \\
\text { adulthood }\end{array}$ & 우 & - & $\begin{array}{l}\text { During } \\
2 \text { years }\end{array}$ & Out \\
\hline & & & $\begin{array}{l}\text { Large unit: } \\
16 \text { with water } \\
\text { Small unit: } 16 \\
\text { with water } \\
\text { Total water: } \\
N=32\end{array}$ & & & & & & & & & \\
\hline \multirow[t]{3}{*}{$\begin{array}{l}\text { Skovgaard } \\
\text { et al. } \\
\text { (1997b) }\end{array}$} & $\begin{array}{l}\text { See Hansen } \\
\text { and Jeppesen } \\
\text { (2000a) }\end{array}$ & $\begin{array}{l}\text { Cleaned and } \\
\text { refilled } \\
\text { weekly }\end{array}$ & $64++16 \widehat{\jmath}$ & $\begin{array}{l}26 / 40 \\
(65 \%)\end{array}$ & $\begin{array}{l}\text {-Behavioural } \\
\text { observation: } \\
\text { Scan sampl. } \\
\text { on } 12 \text { days; } \\
790 \text { single } \\
\text { observations/day }\end{array}$ & $\begin{array}{l}\text {-Stereotypies } \\
\text { behaviour }\end{array}$ & - & Adult & 우 & $\begin{array}{l}\text { "Morning } \\
\text { hours" }\end{array}$ & $\begin{array}{l}24 \text { March } \\
\text { until } 22 \\
\text { June } 1994\end{array}$ & Out \\
\hline & & & $\begin{array}{l}\text { Large unit: } \\
16 \text { with water }\end{array}$ & & & -Activity & & & $0^{+}$ & $\begin{array}{l}\text { After that } \\
\text { scans every } \\
10 \mathrm{~min} . \\
\text { interval }\end{array}$ & & \\
\hline & & & $\begin{array}{l}\text { Small unit: } \\
16 \text { with water } \\
\text { Total water: } \\
N=40\end{array}$ & & & -Place position & & & & & & \\
\hline $\begin{array}{l}\text { Vinke et al. } \\
\text { (2005) }\end{array}$ & $\begin{array}{l}\text { L. } 103 \mathrm{~cm} \times \\
\text { W. } 75 \mathrm{~cm} \text {; } \\
\text { water depth: } \\
45 \mathrm{~cm}\end{array}$ & $\begin{array}{l}\text { Cleaned and } \\
\text { refilled } \\
\text { every } 2 \\
\text { weeks }\end{array}$ & $\begin{array}{l}N=56 ; 2 \\
\text { groups ( } 28 \\
\text { families water; } \\
28 \text { families } \\
\text { no water) }\end{array}$ & $\begin{array}{l}23 \\
\text { families/ } \\
28\end{array}$ & $\begin{array}{l}\text {-Behavioural } \\
\text { observation: } \\
\text { Focal animal } \\
\text { sampling }\end{array}$ & $\begin{array}{l}\text {-e.g. social } \\
\text { and solitary } \\
\text { play behaviour, } \\
\text { activity, rest, } \\
\text { flight, } \\
\text { aggression, } \\
\text { swimming, } \\
\text { diving }\end{array}$ & $\begin{array}{l}\text { Wild } \\
\text { type }\end{array}$ & $\begin{array}{l}7-11 \\
\text { weeks }\end{array}$ & 우 & 9:00-15:00 & June & Out \\
\hline
\end{tabular}




\begin{tabular}{|c|c|c|c|c|c|c|c|c|c|c|c|c|}
\hline \multirow[t]{2}{*}{$\begin{array}{l}\text { Vinke et al. } \\
\text { (2006) }\end{array}$} & $\begin{array}{l}\text { L. } 103 \mathrm{~cm} \times \\
\text { W. } 75 \mathrm{~cm} \text {; } \\
\text { water depth: } \\
45 \mathrm{~cm}\end{array}$ & $\begin{array}{l}\text { Cleaned } \\
\text { and refilled } \\
\text { every } 2 \\
\text { weeks }\end{array}$ & $\begin{array}{l}\text {-Exp 1: } \\
N=56 ; 4 \\
\text { groups (14 } \\
\text { water; } 14 \\
\text { empty bath; } \\
14 \text { palatable } \\
\text { food item; } \\
14 \text { control) } \\
\text {-Exp 2: } \\
N=56 \\
\text { ( } 2 \text { groups; } \\
28 \text { water; } \\
28 \text { no water) }\end{array}$ & - & $\begin{array}{l}\text {-Exp 1: } \\
\text { Anticipatory } \\
\text { behaviour }\end{array}$ & $\begin{array}{l}\text {-Exp 1: } \\
\text { Behavioural } \\
\text { transitions }\end{array}$ & $\begin{array}{l}\text { Wild } \\
\text { type }\end{array}$ & $\begin{array}{l}\text { Exp 1: 16- } \\
24 \text { weeks }\end{array}$ & 우 & $8: 00-15: 30$ & Exp 1: June & Out \\
\hline & & & & & $\begin{array}{l}\text {-Exp 2: IS } \\
\text { sampling } \\
\text {-Included } \\
\text { water } \\
\text { deprivation }\end{array}$ & $\begin{array}{l}\text {-Exp 2: } \\
\text { Stereotypies }\end{array}$ & & $\begin{array}{l}\text { Exp 2: } 41- \\
44 \text { weeks }\end{array}$ & & 8:00-15:30 & $\begin{array}{l}\text { Exp 2: } \\
\text { February }\end{array}$ & \\
\hline \multirow[t]{2}{*}{$\begin{array}{l}\text { Warburton } \\
\text { and Mason } \\
\text { (2003) }\end{array}$} & $\begin{array}{l}\text { L. } 168.5 \mathrm{~cm} \times \\
\text { W. } 68.5 \mathrm{~cm} \text {; } \\
\text { water depth: } \\
60 \mathrm{~cm}\end{array}$ & $\begin{array}{l}\text { Cleaned } \\
\text { every } 2 \\
\text { weeks or } \\
\text { when soiled }\end{array}$ & $N=8$ & $8 / 8$ & $\begin{array}{l}\begin{array}{l}\text { Consumer- } \\
\text { demand (door }\end{array} \\
\text { weights: } 0 \text {, } \\
500,1000,2000 \text {, } \\
3000,4000 \mathrm{~g} \text { ) }\end{array}$ & $\begin{array}{l}\text {-Baseline visit } \\
\text { rates }\end{array}$ & $\begin{array}{l}\text { Wild } \\
\text { type }\end{array}$ & Adult & 우 & $\begin{array}{l}\text { Automa- } \\
\text { tically } \\
24 \mathrm{~h} \\
\text { registration }\end{array}$ & $\begin{array}{l}\text { June 2000- } \\
\text { March } 2001\end{array}$ & In \\
\hline & & & & & & $\begin{array}{l}\text {-Maximum } \\
\text { price paid } \\
\text {-Consumer } \\
\text { surplus } \\
\text {-Visit elasticity } \\
\text {-Expenditure } \\
\text { rate }\end{array}$ & & & & & & \\
\hline
\end{tabular}


bath measures, water hygiene, sample sizes in the experiment, percentage of subjects using the bath, colour type used, age and sex of the subjects, observation time and period).

\subsection{Comments on some features in the available studies}

Focussing on farmed minks' appraisal of swimming water in particular, it should be noted that a limited number of studies is available. In Table 1, it can be seen that most studies used the colour type wild and adult female mink. Also within studies the experimental populations could include some subgroups (see the comments in the column sample size, Table 1). In some studies it was not always clear how the different subgroups (e.g. male vs. female; age) contributed to the results. Age of the subjects did vary between the studies, which makes a comparison between the papers difficult. However, some studies followed the same subjects from juvenile until adulthood, which gives important information on the development of behavioural and physiological pathology in the presence and absence of a swimming bath.

Information on the breeds or the origin of breeds in the papers mostly involved no further details except for the farm in which the minks were bred. Differences in breeds quite probably account for less standardisation in farmed mink research, but standard breeds such as those known in laboratory rats and mice are not available for farmed mink. This situation, however, does not differ from other applied studies on other farm animal species.

Many of the papers used 24-h video recordings, a method we see as appropriate. During daily observations, the animals were observed on randomised reversal schemes. In most studies, the behavioural observations were conducted using a scan sampling and/or a focal animal sampling method, both of which seem to be reliable methods to answer the research questions. Consumerdemand and anticipation tests used other specific parameters which are based on the literature of previous research in mink or other species.

Addressing the season of observations, the available papers cover all months in the year. Studies on juvenile behaviour were conducted during the summer months; this seems appropriate given the normal development of mink. Some studies covered a year or more. Given these differences in time course the studies might best be considered complementary rather than comparable.

Bath designs and measures vary from study to study. Most studies used a bath with a length of more than one meter and a water depth of at least $15 \mathrm{~cm}$. The bath was freely accessible except in consumer demand and deprivation experiments. In all studies the water was cleaned regularly. Thus the hygiene and attractiveness of the water bath was likely similar in the different studies, although none of the research has directly assessed the quality of the swimming water. Surprisingly, most papers do not provide the exact number of animals that actually used the water bath during the study (Table 1). It should also be noted that the sample sizes in some studies might be too small to detect differences, making it difficult to interpret non-significant results.

\subsection{Some specific points of discussion on the results in the available studies}

The studies reviewed showed no clear differences in the occurrence of tail biting, stereotypical and anticipatory behaviour between subjects housed in the presence (water-experienced subjects) or absence (water-naive subjects) of a water bath. Stereotypical behaviour could still be observed in the presence of a water bath (e.g. Skovgaard et al., 1997b; Vinke, 2004), which suggests that the provision of a water bath is not enough to meet all minks' needs in an otherwise barren environment. 
In deprivation experiments, blocking access to a previously experienced water bath might be stressful for farmed mink as shown by increased levels of stereotypical behaviour, tail biting (Korhonen et al., 2003; Vinke, 2004) and cortisol, which might indicate increased stress at least in the short-term (i.e. $<2$ weeks; Mason et al., 2001; Korhonen et al., 2003). The question remains whether the blockage of a previously open entry-door might be frustrating under all kinds of circumstances, whatever is behind the door?

In the case of studies that observe the presence of stereotypical behaviour under farmed conditions, it can be questioned whether this approach is useful (for a discussion on the reliability of stereotypies as welfare indicators see: Mason and Latham, 2004)? This might be of special importance in mink considering the fact that effects might be 'overshadowed' by other management factors in mink farming. Such a prominent influencing factor might be the food management and food delivery in farmed mink, e.g. food deprivation in the winter (see e.g. Bildsøe et al., 1990, 1991; Mason, 1991; Nimon and Broom, 1999). None of the available papers addressed the feeding regimes in detail, and it can still be questioned how food regimes may influence stereotypies during the winter. Another relevant topic that is often unclear in these papers is the level of stereotypies at the start of the study. Preferably one should start with a nonstereotyping population.

Addressing the topics on preference, resource value and play behaviour, swimming water possibly has enriching and rewarding properties for mink as it facilitates exploration (more environmental variability and choices), it may induce play behaviour in juveniles and mink are willing to pay high prices (invest energy) to have access to swimming water in consumer-demand experiments. It should be noted that a water bath might also act as a barrier for some individuals (Hansen and Jeppesen, 2000b, 2001a). Consumer-demand tests showed that mink are willing to invest energy for access to food and a swimming bath (Mason et al., 2001) as well as for access to a running wheel (Hansen and Jensen, 2006a,b), or to a lesser extent, for access to other diverse enrichments (e.g. Mason et al., 2001). In the study of Hansen and Jensen (2006a,b), the experimental mink used the running wheel more than the swimming bath, whereas, the study of Mason et al. (2001) showed that mink preferred the swimming bath compared to other features, i.e. alternative nest site, novel objects, raised platform, toys, tunnel and empty cage. The nonsubstitutability of the running wheel and the swimming bath indicates different underlying motivations to the resources, which might suggest that the importance of each condition for farmed mink should be considered separately.

Rewarding properties of behavioural patterns such as eating, drinking, social contact in social species and unnatural addictive behaviours are characterized by liking and wanting aspects (Berridge, 1996; Berridge and Robinson, 1998). Wanting increases in case of deprivation, and probably underlies vacuum activities, anticipatory behaviour and rebound effects. In the literature, wanting is described to be related to an enhanced sensitivity to reward (Berridge, 1996; Berridge and Robinson, 1998). This enhanced sensitivity of the reward system in the absence of a water bath was not demonstrated in the study of Vinke et al. (2006). However, other studies showed that a subsequent blockage appeared frustrating for mink that had previous contact with swimming water (Mason et al., 2001; Korhonen et al., 2003; Mohaibes et al., 2002, 2003; Vinke, 2004). Apparently, experience does induce wanting which suggests that access to water is an incentive-induced motivation. Access to water for farmed mink might be comparable to running in a running wheel for rodents (running wheel behaviour has been associated with incentive-induced behaviour: e.g. Belke, 1996; Lett et al., 2002; Werme et al., 2002; Rhodes et al., 2003; Vargas-Perez et al., 2003): once they have experienced it, they like it. 


\section{Conclusions}

The scientific discussion on behavioural needs of animals is still ongoing. This paper addressed some physiological and behavioural indicators of welfare, and discussed internal motivation and rewarding properties of behavioural displays, rebound effects and vacuum activities, preferences for, and the value of resources, effects of preventing the performance of (rewarding) behaviours and prior experience, substitutability of alternative resources and a 'positive indicator' of welfare, i.e. play behaviour.

The studies reviewed in this paper provide some insight into minks' motivation for a swimming bath, but are more complementary than comparable. Hence, each study contributes to the understanding of farmed mink's motivation for a water bath. In short, the main conclusions are: (1) The use of a water bath for mink is most likely related to foraging behaviour (foraging areas: land and water); (2) The absence of swimming water, without prior experience, does not lead to consistent changes in level of stereotypic behaviour, or anticipatory responses; (3) The removal of a previously experienced water bath may induce short-term stress as indicated by behavioural parameters ('scratching' and 'scrabbling': Korhonen et al., 2003; Warburton and Mason, 2006, p. 77) and elevated cortisol responses (Mason et al., 2001; Korhonen et al., 2003); (4) Mink work hard for access to a swimming bath and running wheel in consumer demand studies. Other cage modifications such as tunnels and biting objects may also provide environmental enrichment to otherwise impoverished conditions; (5) Individuals differ in how much they value swimming water; (6) Swimming water is likely not an "innate" need; more likely swimming is an incentive that induces its own motivation. We believe that the provision of cage enrichments for farmed mink should be focussed on variability and choices (see Hansen et al., 2007).

Future studies on the following questions would be valuable: (1) do specific environmental cues affect motivation to swim, such as the form of drinking water delivery systems; (2) does prior experience of swimming water affects its incentive value; in other words "can you miss what you never experienced?"; (3) do behavioural parameters such as stereotypic behaviour, rebound effects and vacuum activity have any general utility in assessing the value of absent resources; (4) what are preferences for and the value of alternative resources which may act as substitutes for swimming water? In addition we recommend further work investigating: the relationship between access to swimming water and positive indicators of welfare such as play and anticipatory behaviour; the effects of preventing the performance of rewarding behaviours and deprivation of a previous experienced resource; and health and hygiene issues related to provision of a water bath. In future work, it would be recommended to present the actual percentages of animals using a water bath during the experiment and to provide a power analysis.

\section{Acknowledgements}

We are grateful for the establishment of the Fur Animal Welfare Research Committee (FAWRC) as recommended by the Council of Europe. The studies were conducted under the supervision of the FAWRC and made possible with financial support from the European Fur Breeders' Association (EFBA) and the International Fur Trade Federation (IFTF).

\section{References}

Belke, W., 1996. Investigating the reinforcing properties of running: or, running is its own reward. In: Epling, W.F., Pierce, W.D. (Eds.), Activity anorexia: Theory, Research, and Treatment. Erlbaum, Mahwah, NJ, pp. 45-55. 
Berridge, K.C., 1996. Food reward: brain substance of wanting and liking. Neurosci. Biobehav. Rev. 20 (1), 1-25.

Berridge, K.C., Robinson, T.E., 1998. What is the role of dopamine in reward: hedonic impact, reward learning or incentive salience? Brain Res. Rev. 28, 309-369.

Bildsøe, M., Heller, K.E., Jeppesen, L.L., 1990. Stereotypies in female ranch mink: seasonal and diurnal variations. Scientifur 14, 243-247.

Bildsøe, M., Heller, K.E., Jeppesen, L.L., 1991. Effects of immobility stress and food restriction on stereotypies in low and high stereotyping female ranch mink. Behav. Proc. 25, 179-189.

Birks, J.D.S. 1981. Home range and territorial behaviour of the feral mink. Unpubl. PhD Thesis. University of Exeter, U.K.

Birks, J.D.S., Linn, I.J., 1982. Studies of home range of the feral mink (Mustela vison). Symp. Zool. Soc., Lond. 49, 231257.

Broom, D.M., Johnson, K.G., 1993. Stress and animal welfare. In: Animal Behaviour Series, Chapman \& Hall, London, U.K.

Cabib, S., 1993. Neurobiological basis of stereotypies. In: Lawrence, L.B., Rushen, J. (Eds.), Stereotypic Animal Behaviour. CAB International, Wallingford, U.K, pp. 119-146.

Cabib, S., Puglisi-Allegra, S., 1996. Stress, depression and mesolimbic dopamine system. Psychopharmacology (Berl) 128 (4), 331-342.

Clubb, R., Mason, G., 2003. Captivity effects on wide ranging carnivores. Nature 425, 473-474.

Cooper, J.J., Appleby, M.C., 1995. The effects of experience on motivation: prelaying behaviour in laying hens. Appl. Anim. Behav. Sci. 42, 283-295.

Cooper, J.J., Appleby, M.C., 1996. Demand for nest boxes in laying hens. Behav. Proc. 36, 171-182.

Cooper, J.J., Appleby, M.C., 1997. Motivational aspects of individual variation in reponse to nest boxes by laying hens. Anim. Behav. 54, 1245-1253.

Cooper, J.J., Mason, G.J., 1997. The effect of cost of access on consumption of environmental resources in mink. In: Forbes, J.M., Lawrence, T.L.J., Rodway, R.G., Varley, M.A. (Eds.), Animal Choices. Occasional Publication 20, British Society of Animal Science, U.K, pp. 129-130.

Cooper, J.J., Mason, G.J., 2000. Increasing costs of access to resources cause re-scheduling of behaviour in American mink (Mustela vison): implications for the assessment of behavioural priorities. Appl. Anim. Behav. Sci. 66, 135151.

Cooper, J.J., Albertosa, M.J., 2003. Behavioural priorities of laying hens. Avian and Poultry Biology Reviews 14 (3), 127149.

Cronin, G.M., Wiepkema, P.R., 1984. An analysis of stereotyped behaviour in tethered sows. A. Recherche Véterinaire 15 (2), 263-270.

Cronin, G.M., Wiepkema, P.R., van Ree, J.M., 1985. Endogenous opioids are involved in abnormal behaviour of tethered sows. Neuropeptides 6 (6), 527-530.

Cronin, G.M., Wiepkema, P.R., van Ree, J.M., 1986. Endorphins implicated in stereotypies of tethered sows. Experientia 42 (2), 198-199.

Dawkins, M.S., 1980. Animal suffering. The Science of Animal Welfare. Chapmann Hall, London, U.K.

Dawkins, M.S., 1983. Battery hens name their price: consumer demand theory and the measurement of ethological 'needs'. Anim. Behav. 31, 1195-1205.

Dawkins, M.S., 1988. Behavioural deprivation: a central problem in animal welfare. Appl. Anim. Behav. Sci. 20, 209225.

Dawkins, M.S., 1990. From an animal's point of view: motivation, fitness and animal welfare. Behav. Brain Sci. $13,1-9$.

Dudink, S., Simonse, H., Marks, I., de Jonge, F.H., Spruijt, B.M., 2006. Announcing the arrival of enrichment increases play behaviour and reduces weaning-stress-induced behaviours of piglets directly after weaning. Appl. Anim. Behav. Sci. 101 (1-2), 86-101.

Duncan, I.J.H., Wood-Gush, D.G.M., 1972. Thwarting of feeding behaviour in the domestic fowl. Anim. Behav. 20, 444451.

Duncan, I.J.H., Widowski, T.M., Malleau, A.E., Lindberg, A.C., Petherick, J.C., 1998. External factors and causation of dust bathing in domestic hens. Behav. Proc. 43, 219-228.

Dunstone, N., 1978. The fishing strategy of the mink (Mustela vison); time-budgeting of effort? Behaviour 67 (3-4), 157177.

Dunstone, N., 1979. Swimming and diving behaviour of the mink. Carnivore (Seattle ed.) 56-61.

Dunstone, N., 1993. The Mink. T and AD Poyser, London, U.K.

de Jonge, G., Leipoldt, H., 1994. Grote verrijkte kooien, zwemwater en onrustig gedrag van nertsen. De Pelsdierenhouder 44 (5), 137-143 (Title translation: large enriched cages, swimming water and restless behaviour in mink). 
Fokkema, D.S., Koolhaas, J.M., van der Gugten, J., 1995. Individual characteristics of behavior, blood pressure and adrenal hormones in colony rats. Physiol. Behav. 57 (5), 857-862.

Fox, M. (Ed.), 1968. Abnormal Behavior in Animals. W.B. Saunders Company, Philadelphia. London. Toronto.

Friend, T., 1989. Recognizing behavioural needs. Appl. Anim. Behav. Sci. 22, 151-158.

Gerell, R., 1967. Food selection in relation to habitat in mink (Mustela vison). Oikos 18, 233-246.

Gerell, R., 1970. Home ranges and movements of the mink Mustela vison Schreber in southern Sweden. Oikos 21, 160-173.

Hansen, C.P.B., Jeppesen, L.L., 2000a. Short term behavioural consequences of denied access to environmental facilities in mink. Agric. Food Sci. Finland 9, 149-155.

Hansen, C.P.B., Jeppesen, L.L., 2000b. Effect of blocking farm mink's feed access with open water. Agric. Food Sci. Finland 9, 157-163.

Hansen, C.P.B., Jeppesen, L.L., 2001a. Swimming activity of farm mink (Mustela vison) and its relation to stereotypies. Acta Agric. Scand., Sect. A, Anim. Sci. 51 (1), 71-76.

Hansen, C.P.B., Jeppesen, L.L., 2001b. Use of water for swimming and its relationship to temperature and other factors in farm mink (Mustela vison). Acta Agric. Scand., Sect. A., Anim. Sci. 51 (1), 89-93.

Hansen, C.P.B., Jeppesen, L.L., 2003. The influence of temperature on the activity and water use of farmed mink (Mustela vison). Anim. Sci. 76, 111-118.

Hansen, S.W., 1990. Activity patterns of lactating mink and the effect of water trays and wire netting cylinders in mink cages. Scientifur 14 (4), 187-193.

Hansen, S.W., 1998. The cage environment of the farm mink-significance to welfare. Scientifur 22 (3), $179-185$.

Hansen, S.W., Jensen, M.B., 2006a. Demand for swimming water and running wheel with 1 min of access per reward. Appl. Anim. Behav. Sci. 98 (1-2), 145-154.

Hansen, S.W., Jensen, M.B., 2006b. Quantitative evaluation of the motivation to access a running wheel or a water bath in farm mink. Appl. Anim. Behav. Sci. 98 (1-2), 127-144.

Hansen, S.W., Malmkvist, J., Palme, R., Damgaard, B.M., 2007. Do double cages and access to accupational materials improve the welfare of farmed mink? Anim. Welfare 16, 63-76.

Hernnstein, R.J., 1977. The evolution of behaviorism. Am. Psychol. 32, 593-603.

Horrell, R.I., Ness, P.J.A., Edwards, S.A., Eddison, J.C., 2001. The use of nose-rings in pigs: consequences for rooting, other functional activities, and welfare. Anim. Welfare 10, 3-22.

Hughes, B.O., 1980. The assessment of behavioural needs. In: Moss, R. (Ed.), The Laying Hen and its Environment. Martinus Nijhoff, The Hague, The Netherlands.

Hughes, B.O., Duncan, I.J.H., 1981. Do animals have behavioural needs? Appl. Anim. Ethol. 7, 381-382.

Hughes, B.O., Duncan, I.J.H., 1988. The notion of ethological "need”, models of motivation and animal welfare. Anim. Behav. 36, 1696-1707.

Jensen, P., Toates, F.M., 1993. Who needs "behavioural needs"? Motivational aspects of the needs of animals. Appl. Anim. Behav. Sci. 37, 161-181.

Johnsen, P.F., Vestergaard, K.S., 1996. Dustbathing and pecking behaviour in chicks from a high and a low feather pecking line of laying hens. Appl. Anim. Behav. Sci. 49, 237-246.

Koolhaas, J.M., Korte, S.M., de Boer, S.F., van der Vegt, B.J., van Reenen, C.G., Hopster, H., de Jong, I., Ruis, M., Blokhuis, H., 1999. Coping styles in animals: current status in behavior and stress-physiology. Neurosci. Behav. Rev. 23, 925-935.

Korhonen, H.T., Jauhiainen, L., Niemelä, P., 2003. Effect of swimming deprivation on adrenocortical and behavioural responses in farmed mink (Mustela vison). Ann. Anim. Sci. 3 (1), 145-163.

Kuby, F., 1982. Über die Verhaltensontogenese von Farmnerze (Mustela vison F. Dom.) in Großgehege. Inauguraldissertation zur Erlangung des Grades eines Doctor Medicinae Veterinariae durch die Tierärztliche Hochschule Hannover, Germany (Title translation: The ontogeny of farmed mink (Mustela vison F. Dom.) in a semi-natural housing system. PhD Thesis).

Lawrence, A., 1987. Consumer demand theory and the assessment of animal welfare. Anim. Behav. 35, $293-295$.

Lawrence, A.B., Terlouw, E.M.C., 1993. A review of behavioral factors involved in the development and continued performance of stereotypic behaviors in pigs. J. Anim. Sci. 71, 2815-2825.

Lett, B.T., Grant, V.L., Koh, M.T., Flynn, G., 2002. Prior experience with wheel running produces cross-tolerance to the rewarding effect of morphine. Pharmacol. Biochem. Behav. 72, 101-105.

Lindberg, A.C., Nicol, C.J., 1997. Dust bathing in modified battery cages: is sham dust bathing an adequate substitute? Appl. Anim. Behav. Sci. 55, 113-128.

Martin, G., 1979. Zur Käfighaltung von Legehennen Eine Stellungnahme aus der Sicht der Verhaltenswissenschaft. In: Yeutsch, G.M., von Loeper, E., Martin, G., Müller, J. (Eds.), Intensivhaltung von Nutztieren aus ethischer, rechtlicher und ethologischer Sicht. Basel, Birkhäuser, pp. 101-122. 
Mason, G.J., 1991. Stereotypies: a critical review. Anim. Behav. 41, 1015-1037.

Mason, G.J., 1993a. Age and context affect the stereotypical behaviours of caged mink. Behaviour 127 (3-4), 191-229.

Mason, G.J., 1993b. Forms of stereotypic behaviour. In: Lawrence, A.B., Rushen, J. (Eds.), Stereotypic Animal Behaviour: Fundamentals and Applications to Welfare. CAB International, Oxon, U.K.

Mason, G.J., Mendl, M., 1997. Do the stereotypies of pigs, chickens and mink reflect adaptive species differences in the control of foraging? Appl. Anim. Behav. Sci. 53, 45-58.

Mason, G.J., Latham, N.R., 2004. Can't stop, won't stop: is stereotypy a reliable animal welfare indicator? Anim. Welfare 13, S57-S69.

Mason, G., Cooper, J., Garner, J., 1997. Models of motivational decision-making and how they affect the experimental assessment of motivational priorities. In: Forbes, J.M., Lawrence, T.L.J., Rodway, R.G., Varley, M.A. (Eds.), Animal Choices. Occasional Publication No 20, 1997. British Society of Animal Science, U.K, pp. 9-17.

Mason, G., Clarebrough, C., Cooper, J., 1999. Drink or swim? Using substitutability and physiological responses to frustration to assess the importance of swimming-water for mink. In: Bøe, K.E., Bakken, M., Braastad, B.O. (Eds.), Proceedings of the 33rd International Congress of the International Society for Applied Ethology, 17-21 August 1999, Lillehammer, Norway, p. 83.

Mason, G.J., Cooper, J.J., Clarebrough, C., 2001. Frustrations of fur-farmed mink. Nature 410, 35-36.

Mohaibes, M., Mononen, J., Pyykönen, T., 2003. The effects of swimming pool or extra space on behaviour of mink. In: Proceedings NJF Meeting No. 354. Nordic Association of Agricultural Scientists, 8-10 October 2003, Lillehammer, Norway.

Mohaibes, M., Mononen, J., Pyykönen, T., Kasanen, S., Ahola, L., 2002. Individual variation in swimming motivation in mink: effect of natural and artificial deprivtion. In: Krohn, C.C., Ladewig, J. (Eds.), Proceedings of the 14th Nordic Symposium of the International Society for Applied Ethology, 17-19 January 2002. Danish Institute of Agricultural Sciences, Internal report 151, Tune Landboskole, Denmark, p. 28.

Mohaibes, M., Harri, M., Mononen, J., Pyykönen, T., Kasanen, S., Ahola, L., 2001. Individual variation in swimming motivation in mink. In: Proceedings of the 13th Nordic Symposium of the International Society for Applied Ethology, 25-27 January 2001, Lammi, Finland, p. 15.

Nicol, C.J., Guilford, T., 1991. Exploratory activity as a measure of motivation in deprived hens. Anim. Behav. 41 (2), 333-341.

Nicol, C.J., Lindberg, A.C., Phillips, A.J., Pope, S.J., Wilkins, L.J., Green, L.E., 2001. Influence of prior exposure to wood shavings on feather pecking, dust bathing and foraging in adult laying hens. Appl. Anim. Behav. Sci. 73, $141-155$.

Nimon, A.J., Broom, D.M., 1999. The welfare of farmed mink (Mustela vison) in relation to housing and management: a review. Anim. Welfare 8, 205-228.

Panksepp, J., 1998. Affective Nueroscience. The foundations of human and animal emotions. Oxford University Press, New York, U.S.A.

Panksepp, J., Burgdorf, J., 2003. Laughing" rats and the evolutionary antecedents of human joy? Physiol. Behav. 79, 533547.

Petherick, J.C., Seawright, E., Waddington, D., Duncan, I.J.H., Murphey, L., 1995. The role of perception in the causation of dustbathing behaviour in domestic fowl. Anim. Behav. 49, 1521-1530.

Piazza, P.V., Deminiere, J.M., Le Moal, M., Simon, H., 1990. Stress- and pharmacologically induced behavioural sensitization increases vulnerability to acquisition of amphetamine self-administration. Brain Res. 514 (1), $22-26$.

Poole, T.B., 1992. The nature and evolution of behavioural needs in mammals. Appl. Anim. Behav. Sci. 1, $203-220$.

Poole, T.B., Dunstone, N., 1976. Underwater predatory behaviour of the American mink (Mustela vison). J. Zool. Lond. $178,395-412$.

Price, E.O., 1999. Behavioural development in animals undergoing domestication. Appl. Anim. Behav. Sci. 65, $245-271$.

Rhodes, J.S., Garland Jr., T., et al., 2003. Patterns of brain activity associated with variation in voluntary wheel-running behavior. Behav. Neurosci. 117 (6), 1243-1256.

Rushen, J., Lawrence, A.B., Terlouw, C.E.M., 1993. The motivational basis of stereotypies. In: Lawrence, A.B., Rushen, J. (Eds.), Stereotypic Animal Behaviour: Fundamentals and Applications to Welfare. CAB International, Wallingford, Oxon, U.K, pp. 41-64.

Schultz, W., 1998. Predictive reward signal of dopamine neurons. J. Neurophysiol. 80, 1-27.

Schultz, W., 2000. Multiple reward signals and the brain. Nat. Rev. Neurosci. 1, 199-207.

Sinclair, W., Dunstone, N., Poole, T.B., 1974. Aerial and underwater visual acuity in the mink Mustela vison Schreber. Anim. Behav. 22, 965-974.

Skovgaard, K., Jeppesen, L.L., Hansen, C.P.B., 1997a. Would you like a swim Madam mink? Scientifur 21 (4), $247-251$.

Skovgaard, K., Jeppesen, L.L., Hansen, C.P.B., 1997b. The effect of swimming water and cage size on the behaviour of ranch mink (Mustela vison). Scientifur 21 (4), 253-260. 
Spruijt, B.M., van Hooff, J.A.R.A.M., van Gispen, W.H., 1992. Ethology and Neurobiology of grooming behavior. Phys. Rev. 72 (3), 825-852.

Spruijt, B.M., van den Bos, R., Pijlman, F.T.A., 2001. A concept of welfare based on reward evaluating mechanisms in the brain: anticipatory behaviour as an indicator for the state of reward systems. Appl. Anim. Behav. Sci. 72, $145-171$.

Studnitz, M., Jensen, K.H., 2002. Expression of rooting motivation in gilts following different lengths of deprivation. Appl. Anim. Behav. Sci. 76, 203-213.

Tauson, A.H., 1999. Water intake and excretion, urinary solute excretion and some stress indicators in mink (Mustela vison). Effect of ambient temperature and quantitative water supply to adult males. Anim. Sci. 69, 171-181.

Terlouw, E.M.C., Lawrence, A.B., Ilius, A.W., 1991. Influences of feeding levels and physical restriction on development of stereotypies in sows. Anim. Behav. 42, 981-991.

Thorpe, W.H. 1965. The assessment of pain and distress in animals. In: Report of the Technical Committee to Enquire into the Welfare of Animals kept under Intensive Livestock Systems. Command paper 2836. pp. 125-134. London, U.K.: HMSO.

Tuyttens, F.A.M., 2005. The importance of straw for pig and cattle welfare: a review. Appl. Anim. Behav. Sci. 92, 261282.

van Liere, D.W., Wiepkema, P.R., 1992. Effects of long term deprivation of sand on dust bathing behaviour in laying hens. Anim. Behav. 43, 549-558.

van den Berg, C.L., 1999. Play Deprivation, long-lasting consequences of juvenile isolation in rats; involvement of opioid systems. PhD Thesis, University of Utrecht. Ponsen \& Looijen BV: Wageningen, The Netherlands.

van den Berg, C.L., Hol, T., Everts, H., Koolhaas, J.M., van Ree, J.M., Spruijt, B.M., 1999a. Play is indispensable for an adequate development of coping with challenges in the rat. Dev. Psychobiol. 34 (issue 2), 129-138.

van den Berg, C.L., Pijlman, F.T.A., Koning, H.A.M., Diergaarde, L., Van Ree, J.M., Spruijt, B.M., 1999b. Isolation changes the incentive value of sucrose and social behaviour in juvenile and adult rats. Behav. Brain Res. 106, $133-142$.

van der Harst, J.E., 2003. Tools to measure and improve welfare of laboratory rats: reward-related behaviour and environmental enrichment. $\mathrm{PhD}$ thesis, Veterinarian Faculty, Utrecht University. Optima Grafische Communicatie: Rotterdam, The Netherlands.

van der Harst, J.E., Baars, A.M., Spruijt, B.M., 2003. Standard housing for rats is stressful as shown by enhanced sensitivity to rewards. Behav. Brain Res. 142, 151-156.

VanderSchuren, L.J.M.J., Spruijt, B.M., Hol, T., Niesink, R.J., van Ree, J.M., 1995a. Sequential analysis of social play behavior in juvenile rats: effects of morphine. Behav. Brain Res. 72 (1-2), 89-95.

VanderSchuren, L.J.M.J., Stein, E.A., Wiegant, V.M., van Ree, J.M., 1995b. Social play alters regional brain opioid receptor binding in juvenile rats. Brain Res. 680 (1-2), 148-156.

VanderSchuren, L.J., Niesink, R.J., van Ree, J.M., 1997. The neurobiology of social play behavior in rats. Neurosci. Biobehav. Rev. 21 (3), 309-326.

van Ree, J.M., Gerrits, M.A.F.M., VanderSchuren, L.J.M.J., 1999. Opioids, reward and addiction: an encounter of biology, psychology, and medicine. Pharmacol. Rev. 51 (2), 341-396.

Vargas-Perez, H., Mena-Segovia, J., et al., 2003. Induction of c-fos in nucleus accumbens in naive male balb/c mice after wheel running. Neurosci. Lett. 352 (2), 81-84.

Veasey, J.S., Waran, N.K., Young, R.J., 1996. On comparing the behaviour of zoo housed animals with wild conspecifics as a welfare indicator. Anim. Welfare 5, 13-24.

Vestergaard, K.S., 1980. The regulation of dust bathing and other behaviour patterns in the laying hen: a Lorenzian approach. In: Moss, R. (Ed.), The Laying Hen and its Environment. Martinus Nijhoff, The Hague, The Netherlands, pp. 101-120.

Vestergaard, K.S., 1982. Dust-bathing in the domestic fowl-diurnal rhythm and dust deprivation. Appl. Anim. Ethol. 8, 487-495.

Vestergaard, K.S., Skadhauge, E., Lawson, L.G., 1997. The Stress of not being able to perform dustbathing in laying hens. Physiol. Behav. 62 (2), 413-419.

Vestergaard, K.S., Damm, B.I., Abbott, U.K., Bildsøe, M., 1999. Regulation of dustbathing in feathered and featherless domestic chicks: the Lorenzian model revisited. Anim. Behav. 58, 1017-1025.

Vinke, C.M., 2004. Cage enrichments and the welfare of farmed mink. PhD Thesis, Utrecht University. Universal Press, Veenendaal, The Netherlands (ISBN: 90-393-3707-1).

Vinke, C.M., de Buisonjé, F., Wassink, A., 2004a. Kooiverrijkingen en welzijn van nertsen. De Pelsdierenhouder, JulyAugust (in Dutch). (Translation: Cage enrichments and welfare of mink).

Vinke, C.M., van den Bos, R., Spruijt, B.M., 2004b. Anticipatory activity and stereotypical behaviour in American mink (Mustela vison) in three housing systems differing in the amount of enrichments. Appl. Anim. Behav. Sci. 89, 145161. 
Vinke, C.M., Van Leeuwen, J., Spruijt, B.M., 2005. Juvenile farmed mink (Mustela vison) with additional access to swimming water play more frequently than animal housed with cylinder and platform, but without swimming water. Anim. Welfare 14, 53-60.

Vinke, C.M., Houx, B.B., van den Bos, R., Spruijt, B.M., 2006. Anticipatory behaviour and stereotypical behaviour in farmed mink (Mustela vison) in the presence, absence and after the removal of swimming water. Appl. Anim. Behav. Sci. 96, 129-142.

von Frijtag, J.C., 2001. Long-term effects of social stress in rats. The assessment of animal welfare using a model of human depression. PhD Thesis, Utrecht University, The Netherlands.

von Frijtag, J.C., van den Bos, R., Spruijt, B.M., 2002. Imipramine restores the long-term impairment of appetitive behaviour in socially stressed rats. Psychopharmacology 162, 232-238.

von Frijtag, J.C., Reijmers, L.G.J.E., van der Harst, J.E., Leus, I., van den Bos, R., Spruijt, B.M., 2000. Defeat followed by individual housing results in long-term impaired reward- and cognition-related behaviours in rats. Behav. Brain Res. 117 (1-2), 137-146.

von Frijtag, J.C., Kamal, A., Reijmers, L.G.J.E., Schrama, L.H., van den Bos, R., Spruijt, B.M., 2001. Chronic imipramine treatment partially reverses the long-term changes of hyppocampal synaptic plasticity in socially stressed rats. Neurosci. Lett. 309, 153-156.

Warburton, H., Mason, G., 2003. Is out of sight out of mind? The effects of resource cues on motivation in mink. Mustela vison. Anim. Behav. 65, 755-762.

Warburton, H., Mason, G., 2006. Substitutability effects in a closed economy preference set-up: an example using mink. In: Mendl, M., Bradshaw, J.W.S., Burman, O.H.P., Butterworth, A. (Eds.), Proceedings of the 40th Congress of the ISAE, 8-12th August 2006, University of Bristol, U.K, p. 77.

Wechsler, B., 1991. Stereotypies in polar bears. Zoo Biol. 10, 177-188.

Werme, M., Messer, C., Olson, L., Gilden, L., Thoren, P., Nestler, E.J., Brene, S., 2002. Delta FosB regulates wheel running. J. Neurosci. 22, 8133-8138.

Widowski, T.M., Duncan, I.J.H., 2000. Working for a dustbath: are hens increasing pleasure rather than reducing suffering? Appl. Anim. Behav. Sci. 68, 39-53. 